\title{
NEW HOPE ON DRUG LEADS DEVELOPMENT FROM DEEP OCEAN: HALOGENATED ALKALOIDS OF AGELAS SPONGES
}

\author{
Triana Hertiani
}

Faculty of Pharmacy, Universitas Gadjah Mada, Sekip Utara, Yogyakarta, Indonesia 55281

Submitted: 04-05-2014 Revised: 05-07-2014

Accepted: 08-09-2014

*Corresponding author Triana Hertiani

Email :

hadna3ana@yahoo.com

\begin{abstract}
Agelas sponge is found in abundancy from Indonesia's ocean. This sponge produces an important chemotaxonomic group of compounds, derived from pyrrole-imidazole alkaloids. This group of compounds is one of those exclusively found from marine environment. Marine sponges are reported to be promising drug lead producers having unique chemical structures of which many have no terrestrial counterparts. The objective of this report is to give an overview of the reported attempts from up to down stream to develop pyrrole-imidazole alkaloids as new drug lead. Literatures up to 2013 reporting this group of compounds from Agelas sponges were studied. Discussion on the halogenated alkaloids covers the producers, description of high chemical diversity, identification, biosynthesis and ecological relevance as well as their role as a promising drug candidate. Alternatives to provide continous supplies for drug development are also discussed considering that wild harvesting of the sponge producers can lead to ecological damage in the future. Broad range of interesting pharmacological importance as well as several success in developing synthetic route for production supports its development as drug candidate.
\end{abstract}

Key words: Agelas, halogenated alkaloids, drug lead, sponge

\section{INTRODUCTION}

A coverage of almost $75 \%$ of the Earth's surface has positioned the ocean as the major producer of natural products (Whitehead, 1999). Unlike its terrestrial counterpart, unique structures has been encountered and the utilization has lack of ethno-medical history. This issue together with technical difficulties in collecting marine organisms held back the development of marine-derived natural products as therapeutic agents. Nevertheless, synergism collaboration involving pharmaceutical companies, academic institutions, governmental and so non-governmental agencies, has made a significant progress in form of systemic investigations directed towards the collection and characterizations of marine natural products, as well as the evaluation of their biological activity (Christian et al., 1997; Amador et al., 2003). Large numbers of novel marine-derived compounds reported in the literatures in the last decades exhibit the positive development (Mayer and Gustafson, 2003; Amador et al., 2003). Some promising agents which are naturally derived or the synthetic derivates have entered preclinical and also clinical trials which can be expected that the number will increase in the near future (Amador et al., 2003).

According to Proksch and co-workers (2002), the majority of marine natural products currently in clinical trial or under clinical evaluation are produced by invertebrates. The soft bodied, sessile or slow-moving marine invertebrates having lack of morphological defense structure in form of spines or a protective shell make them more vulnerable for predation which justifies the ecological importance of utilizing chemical constituents for surveillance in the respective invertebrates (Proksch et al., 2002).

Database provided by MarinLit (2002) shows that the source of new marine natural products is dominated by sponges (37\%) followed by coelenterates $(21 \%)$. Blunt et al. in a review of marine natural products (2005) and Hu et al. (2011) supported the above mentioned statement. This data somehow define the role of marine invertebrates as a potential source of new drug candidates. Up to now more than 17,000 marine products have been described (MarinLit, 2006) of which sponges are 
responsible for more than 5300 different products (Faulkner 2000, 2001, 2002). Moreover, the chemical diversity of sponge products is remarkable, in addition to the unusual nucleosides, bioactive terpenes, sterols, cyclic peptides, alkaloids, fatty acids, peroxides, and amino acid derivatives (which are frequently halogenated) (Sipkema et al., 2005).

Pharmaceutical interest in sponges itself was aroused in the early 1950s by the discovery of the unusual nucleosides spongothymidine and spongouridine in the marine sponge Cryptotetbia crypta (Bergmann and Feeney, 1950, 1951). These nucleosides were the basis for the synthesis of Ara-C, the first marine-derived anticancer agent, and the antiviral drug Ara-A (Prokch et al., 2002).

As also found in terrestrial metabolites, many of marine natural products act as regulators of specific biological functions. Some of them have pharmacological activity due to their specific interactions with receptors and enzymes which are not found in their terestral counterpart. Marine metabolites face the problem that they become immediately diluted by large volumes of seawater of which requires a highly potency on a molecular basis and retains a relatively low solubility (McConnel et al., 1994). It has been repeatedly shown that the accumulation of toxic or distasteful natural product is an effective strategy to repel potential predators (e.g. fishes) or in a competition for living space (Proksch $e t$ al., 2002; Proksch and Ebel, 1998; Proksch, 1999; McClintock and Baker, 2001). These secondary metabolites, which are produced as a result of evolutionary pressures to reserve or enhance an organisms ecological success (Proksch, 1999), have evolved into structurally diverse and usually stereo-chemically complex compounds with specific biological activity (Edrada et al., 2000) many of which belong to novel chemical groups solely found in marine environment (Carte, 1993).

The Agelas sponges classification falls into phylum Porifera; class Demospongiae; order Agelasida; family Agelasidae and genus Agelas. This sponge found in abundance in Indonesia suggesting evolutionary fittness. Agelas linnaei, A. nakamurai (Hertiani et al., 2010;
Murti, 2006; Eder et al., 1999), and $A$. nemoecinata (Pedradab, 2005) were examples of secondary metabolite producers from the Agelas collected from Indonesia sea, of which A. nakamurai as the most reported sponge from this genus (Hertiani et al., 2010; Murti, 2001, 2006; Sapar et al., 2013; Eder et al., 1999; Trianto, 2005). Several other reports on this particular sponge are also derived from the neighbour sea, Papua New Guinea (Iwagawa et al., 1998). Many pharmacological-interesting compounds found in these particular sponges including the marine specific halogenated alkaloids.

\section{Halogen containing metabolites}

Marine sponges are a rich source of highly halogenated compounds. They may function to resist feeding by fish and fouling by barnacles, bacteria, and fungi (Gribble, 2004). One of the widest group of halogenated alkaloids are bromine-containing alkaloids (Dembitsky and Tolstikov, 2003). High halogen concentration in sea water has a consequence of its contribution in the biosynthesis of some marine metabolites. Catalyzed by haloperoxidases, halogenide anions from sea-water are oxidized (Hoffmann and Lindel, 2003) and then incorporated into organic compounds by specific halogenases (Van Pee, 2001). Enormous reactivity towards electrophilic halogenation reactions is probably the cause why heteroatom containing secondary metabolites such as pyrroles, indoles, phenols, and tyrosines are commonly found to be halogenated in sponges. Despite the relative concentrations of chloride, bromide and iodide ions exist in sea water $(559 \mathrm{mM}, 0.86 \mathrm{mM}$ and $0.45 \mu \mathrm{M}$ respectively); marine organisms oxidize more bromide than chloride for incorporation into organic compounds (Faulkner, 1995). This may reflect the higher importance of bromoperoxidase (BPO) relative to chloroperoxidase $(\mathrm{CPO})$ in marine life, and underline the fact that chlorine cannot be oxidized to active chlorine by BPO (Gribble, 1996b, 1998). Therefore bromide ions have greater ease to be oxidized and give bromonium species which react readily as electrophils with unsaturated species (Whitehead, 1999). 
Brominated pyrroles have been isolated on several occasions as major constituents of marine sponges. Many of the simpler members of this class of compounds are structurally related as they comprise two heterocyclic rings linked by a linear chain (Whitehead, 1999). Over the last thirty years, numerous similar alkaloids with various structures and interesting biological activities have been isolated essentially (but not exclusively) from various species of Agelasidae, Hymeniacidonidae and Axinellidae (Williams and Faulkner, 1996).

\section{Characterization of halogenated alkaloids by LC/MS}

The presence of bromine and chlorine in a molecule can be easily distinguished from the molecular ion peak shown by their mass spectra. The molecular ions of chlorine and bromine-containing compounds will show multiple peaks due to the fact that each halogen exists as two isotopes. While ${ }^{79} \mathrm{Br}$ and ${ }^{81} \mathrm{Br}$ exist in relatively equal abundance, the natural chlorine isotopes consist of $75.77 \%$ of ${ }^{35} \mathrm{Cl}$ and of $24.23 \%{ }^{37} \mathrm{Cl}$ (Smith, 2005). Thus the molecular ion of a chlorine-containing compound will have two peaks, separated by two mass units, in an intensity ratio of $\approx 3: 1$, while in a bromine-containing compounds these two peaks occur in approximately equal intensities. Therefore the presence of one bromine in a molecule e.g. in mukanadin $\mathrm{C}$ will be represented by two molecular ion peaks having a difference of two mass units in an equal height. In the meantime, the presence of two bromines as in midpacamide will appear as three molecular ion peaks having a difference of two mass units in an intensity ratio of 1:2:1. Furthermore in a compound bearing three bromines such as aplysamine-2, the molecular ion will appear as multiple peaks having two mass unit differences in a ratio of 1:2:2:1 (Hertiani et al., 2009; Hertiani et al., 2010).

The presence of fluorine and iodine, by contrast, is mono isotopic, having masses of 19 and 127 amu respectively (Smith, 2005). Thus neither fluorine nor iodine substitution will cause the above phenomenon as can be observed in agelanesin B and agelanesin D (Hertiani et al., 2010).
A distinct pseudomolecular ion pattern of brominated compounds in LC/MS is very important for preliminary characterization. This method can easily distinguish the presence of different brominated metabolites from sponge crude extracts. In LC/MS, after having the HPLC separation, the resulted peaks are detected by the UV detector and mass spectrometer. As more compounds can share the same UV pattern, the possibility of sharing the same molecular weight is less. In the case of brominated compounds, it is very rare to find different compounds having the same molecular weight with the same degree of bromination.

\section{Structural diversity of pyrrole-imidazole alkaloids in Agelas sponges}

Pyrrole-imidazole alkaloids are exclusively found in marine sponges, mainly of the families Agelasidae, Axinellidae, and Halichondridae. The underlying $\mathrm{C}_{11} \mathrm{~N}_{5}$ building block consists of a pyrrolyl-2-carbonyl unit being connected via an amide linkage to a 2amino-5-(3-amino) propylimidazole partial structure (Lindel et al., 2000a). The pyrrole-2carbonyl unit can be non-, mono-, or dibrominated in the 4- and 5- positions. Bromination of the pyrrole 3-position or of the imidazole part has not been observed (Hoffmann and Lindel, 2003). In some metabolites, the linear chain is cyclized to form an $\mathrm{AB}$ core of a pyrrolopyrazinone bicyclic system such as in dibromophakellin, agelastatin $\mathrm{A}$, pala'uamine, longamide $\mathrm{A}$, and cyclooroidin (Figure 1) (Jacquot et al., 2004).

A comparison of bromopyrrole congeners reported from Agelas nakamurai and Agelas linnaei reveals interesting finding (Figure 2). In the $A$. nakamurai most reported congeners are monobrominated (Hertiani et al., 2010; Murti, 2006; Uemoto et al., 2009; Iwagawa et al., 1998) or dimers of monobrominated monomers (Eder et al., 1999), with an exception in Ageladine A (Most of $A$. linnaei metabolites, the pyrrole rings are dibrominated with exception of agelanesin $\mathrm{A}$, agelanesin $\mathrm{B}$ and agelongine which are monobrominated. Another difference observed is that all metabolites of $A$. nakamurai found in 


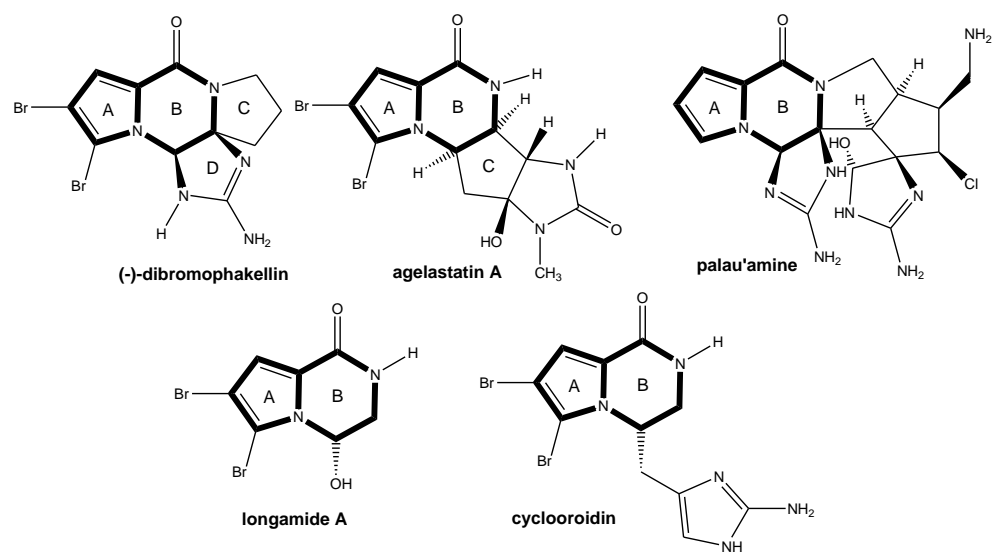

Figure 1. Example of pyrrole-imidazole compounds having a pyrrolopyrazinone bicyclic system (Jacquot et al., 2004).

\section{A. linnaei mebolites}

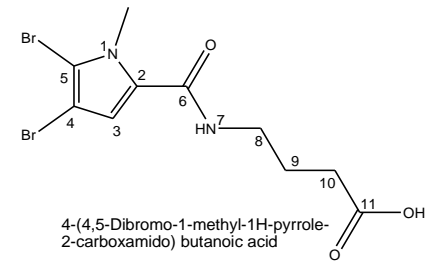

No reported congener
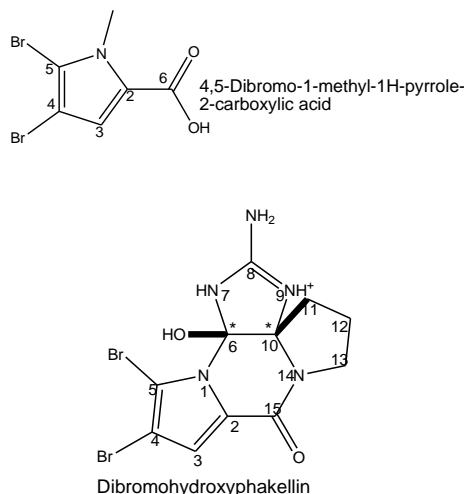
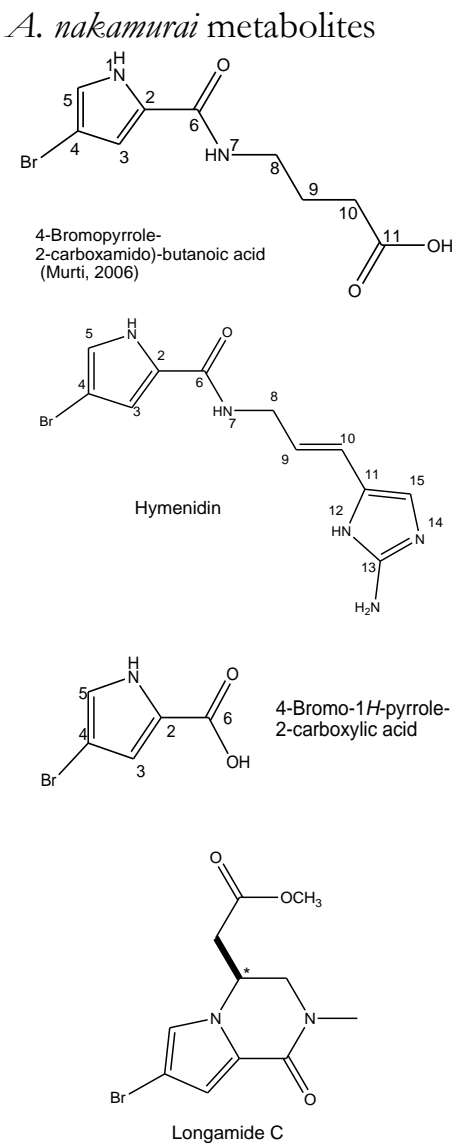

A. nemoecinata metabolites

No reported congener

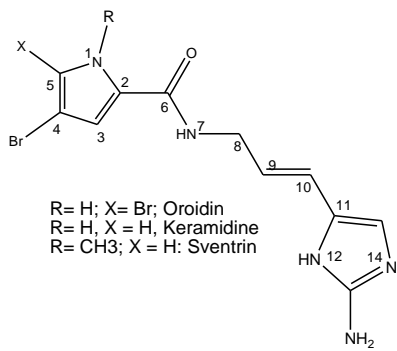

No reported congener

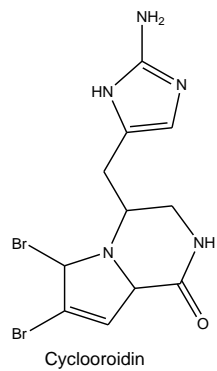

Figure 2. Selected pyrrole-imidazole compounds isolated from A. linnaei (Hertiani et al., 2010) and A. nakamurai (Hertiani et al., 2010; Murti, 2005) and from A. nemoecinata (Pedradab, 2005) showing the similarities and differences in the structure of related compound.

* Only relative stereochemistry is shown 
this study have a free NH pyrrole while in most of the A. linnaei metabolites, the $\mathrm{NH}$ pyrrole is methylated. A clear example is provided by the presence of 4-bromo- $1 \mathrm{H}$-pyrrole-2-carboxylic acid in $A$. nakamurai, and its dibrominated $N$ methyl pyrrole congener in $A$. linnaei (Hertiani et al., 2010). Furthermore, an analogue of the $A$. linnaei metabolite, 4-(4,5-dibromo-1-methyl- $1 H$ pyrrole-2-carboxamido) butanoic acid was previously reported from $A$. nakamurai as 4bromo-2-carboxamido-butanoic acid (Murti, 2006). Other finding reported by Pedradab (2005) revealed the presence of di-brominated brompyrroles i.e.: Slagenin D and E, Oroidin, Dehydrooroidin, Cyclooroidin, and monobrominated derivates, i.e. Slagenin A, Sventrin and Keramadine from $A$. nemoecinata.

The pyrrole-imidazole compounds isolated from $A$. linnaei were comprised of high structural diversity, introducing some new functionality. A new compound related to midpacamide, Agelanin B displays an unusual 3-hydroxyl-4-oxo-pentanoic acid instead of a hydantoin ring. Agelanin A introduces a unique functionality as the propylamide chain is cylized to form a dihydroimidazopyridinol ring. Despite its very rare mode of cyclization, a related structure was previously reported as dibromoagelaspongin, a phakellin related compound isolated from Tanzanian sponge Agelas sp. (Fedoreyev et al., 1989). The phakellins itself exhibit a unique array of functionality including a cyclic guanidine, a pyrrole carboxylic acid, a pyrrolidine, and a congener with potentially delicate vicinal diaminal stereocenters (Poullennec et al., 2002).

More amino acid precursors may be involved in the structure of agelanesins and the mauritamides. In agelanesin, the imidazole ring is replaced with a halogenated tyramine. Taurine related compounds are encountered in two mauritamide A congeners, mauritamide $\mathrm{B}$ and $\mathrm{C}$, along with a quite simple compound 2(4,5-dibromo-1-methyl-1H-pyrrole-2-

carboxamido) ethanesulfonic acid. Moreover, a co-occurrence of the known serotonergic agent, agelongine with its pyridinium ring in the structure to replace the imidazole nucleus and an ester linkage to replace the amidic bond (Cafieri et al., 1995) is also isolated from this $A$. linnaei sponge.

\section{Brominated pyrroles: UV spectra characteristics}

Databases of this group of compounds revealed their distinct UV spectra due to a shared chromophore, a pyrrole-2-carbonyl ring. According to Jaffe and Orchin (1962), a maximum absorption at around $270 \mathrm{~nm}$ is detected for this particular group.

Comparison of several pyrrole imidazole alkaloids showed different characteristics in their UV spectra (Figure 3a). Pyrrole imidazoles having an additional tyramine in the molecules experience reduced intensity of the absorption band at around $270 \mathrm{~nm}$ and have an increase of the absorption band at around $210 \mathrm{~nm}$ which represent the additional phenolic unit (Figure 3b). A cyclization of the linear chain to form the pyrrolopyrazinone bicyclic system as can be observed in mukanadin $\mathrm{C}$, longamide $\mathrm{C}$, as well as in the phakellins intensifies the absorption band at around 230nm (Figure 3d). Agelanin A, on the other hand, forms a cyclization between $\mathrm{N}-7$ and the imidazole ring which causes a major modification. A pronounced bathocromic shift of the major band to $\lambda 340 \mathrm{~nm}$ is observed (Figure 3a) (Hertiani et al., 2010). This kind of bathocromic shift can also be observed in hymenialdisins (Figure 3e) (Baker, 2004). Stevensine which differs in the imidazoline ring part, loses the second band and only shows a major peak at around $240 \mathrm{~nm}$, while in 2bromoaldisin the second band is encountered at around $315 \mathrm{~nm}$ (Pedradab, 2005).

\section{Brominated pyrroles: biosynthesis aspect}

Despite the importance on pharmacological activities and chemotaxonomic considerations (Braekman et al., 1992), knowledge on pyrrole-imidazole alkaloids biosynthesis remains in question (Travert and Al-Mourabit, 2004). Symbiotic microorganisms were suggested to play a role in the biosynthesis based on the fact that bromopyrole alkaloids is reported from an assortment of sponge genera. Moreover, populations of heterotrophic bacteria were found in Carribean sponge Agelas conifera,. Nevertheless, cellular localization studies by differential centrifugation and Ficoll density gradients demonstrated that oroidin and sceptrin were associated with sponge spherulous cells and not with the bacterial fraction (Richelle-Maurer et al., 2003). 
A
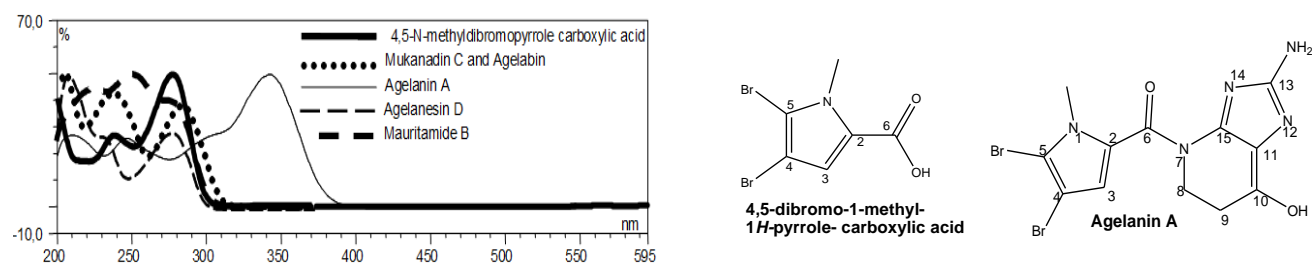

B
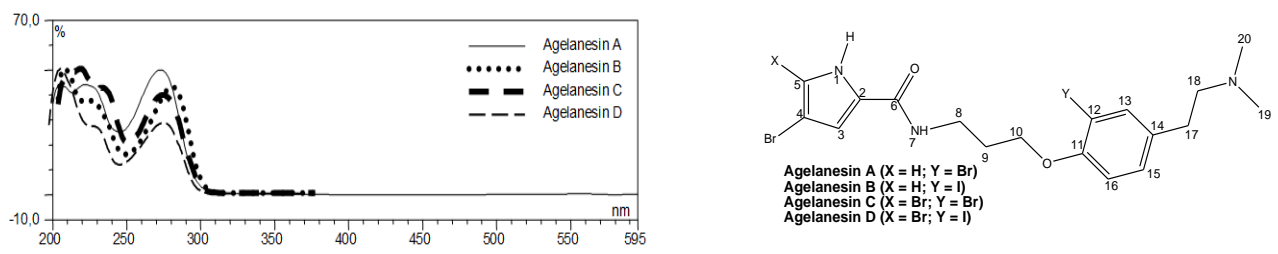

$\mathrm{C}$
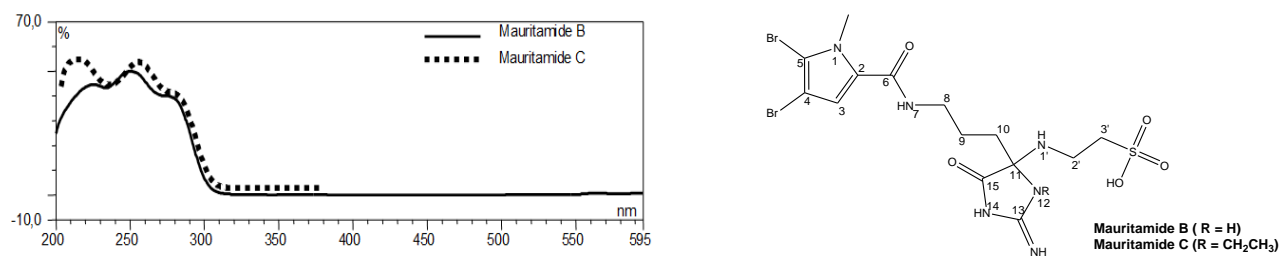

$\mathrm{D}$
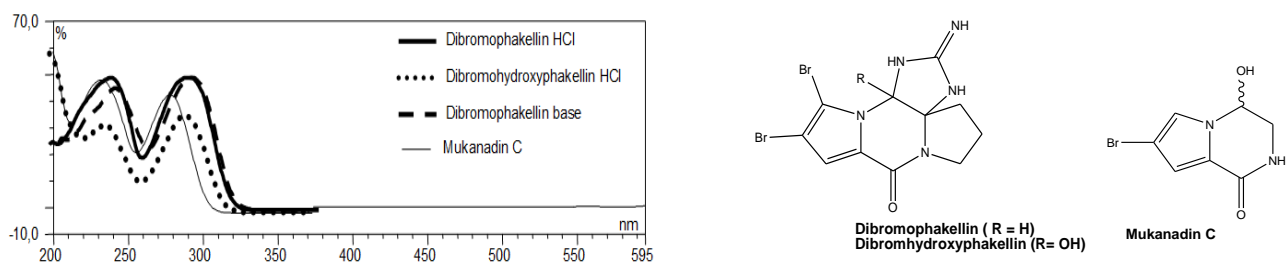

$\mathrm{E}$
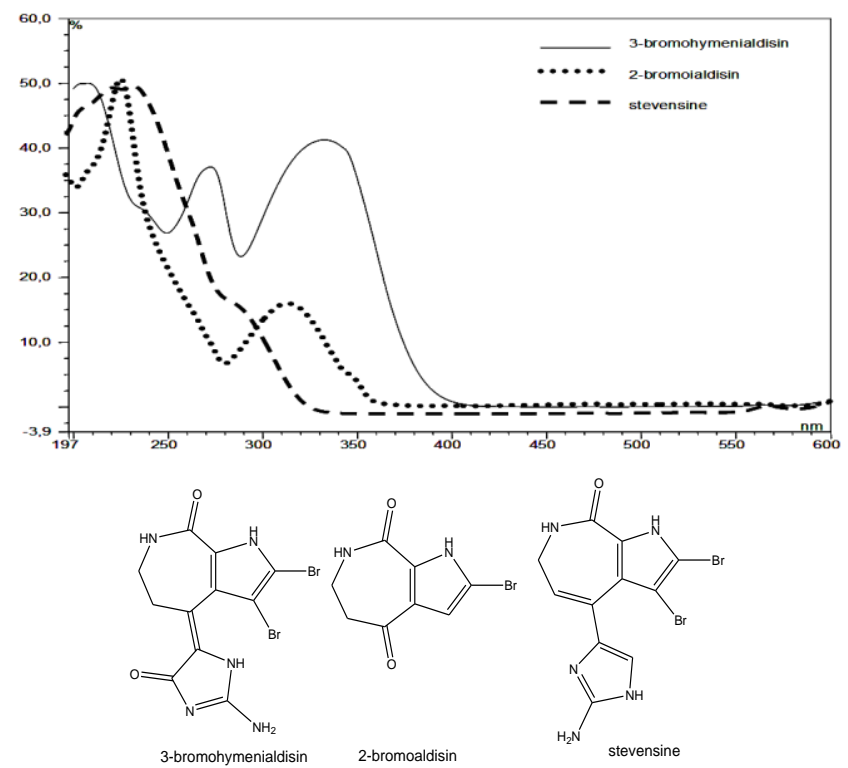

Figure 3. UV absorption pattern of several pyrrole imidazole alkaloids.

Note: a-d are from Agelas linnaei and Agelas nakamurai (Hertiani, 2007); e was modified from Baker, 2004; Pedradab, 2005) 
Several studies showed that spherulous cells, when present, are producers of the bioactive metabolites (Marin et al., 1998; Müller et al., 1986; Salomon etal.,2001; Thompson et al.,1983; Turon et al., 2000; Uriz et al., 1996; Richelle-Maurer et al., 2003). The production of an oroidin dimer, stevensine, by adding amino acid precursors into a sponge cells culture performed by Andrade et al. (1999) supports that these alkaloids are produced by sponge cell and not by symbiont (Richelle-Maurer et al., 2003).

A shared biosynthetic pathway is proposed for pyrrole imidazole alkaloids based on a common key metabolite, oroidin ( $\mathrm{Al}$ Mourabit and Potier, 2001; Hoffmann and Lindel, 2003). Several alternatives have been discussed with regard to their biosynthesis. While the pyrrole part is generally expected to be derived from proline/ornithine, different proposals have been put forward for the 2amino-5-(3-amino) propylimidazole part (Lindel et al., 2000a). Considering that the metabolism of proline in some plants and microorganisms is known to be stress dependent (Hare and Cress, 1997; Ballantyne and Storey, 1983), even though the ecological role of proline in sponges is not known, its role under stress conditions is assumed crucial for surveillance. Thus, if proline is involved in $\mathrm{C}_{11} \mathrm{~N}_{5}$ formation under oxidative conditions, this would be in accordance with the ecological role of "oroidin-based" alkaloids used by sponges as a chemical arsenal for their defense (Travert and Al-Mourabit, 2004).

Braekman and collaborators (1992) proposed that proline, ornithine, and guanidine are probable precursors of both the bromopyrrole and 2-aminoimidazolinone moieties, based on the fact that proline and ornithine are two closely related amino acids of the glutamate group and the oxidation of proline into pyrrole-2-carboxylic acid is a general catabolic pathway (Michal, 1972). Saxitoxin which is an analogue of aminopropylimidazole has been reported to be arouse from ornithine (Shimizu et al., 1984). Other finding revealed the occurence of girolline with its linear or cyclized pyrrole derivatives in "Pseuodaxynissa" cantharella (Ahond et al., 1988), suggests the biosynthetic pathway of these alkaloids proceeds by formation of an amide bond between a pyrrole-2-carboxylic acid precursor and an amino propylimidazole moiety (Braekman et al., 1992).

Hoffmann and Lindel (2003) suggested a different pathway of which ornithine is incorporated into proline, and being oxidized to form the pyrrole-2-carboxylic acid moiety. A biosynthetic experiment performed by Andrade and collaborators (1999) in the sponge cell cultures revealed that $\left[{ }^{14} \mathrm{C}\right]$-labeled proline, ornithine, and histidine were incorporated into stevensine. Natural compounds 3-amino-1-(2aminoimidazolyl)-prop-1-ene and 4,5-dibromopyrrole carboxylic acid were proposed as intermediates (Andrade et al., 1999). Furthermore, Hoffman and Lindel (2003) proposed that if histidine is a biogenetic precursor, the natural product clathramide $A$ could be a biogenetic intermediate in Agelas clathrodes (Cafieri et al., 1998a; Cafieri et al., 1996). The missing carbon atom would be incorporated into the histidine-derived portion via methylation of the imidazole 5-portion, followed by conversion of clathramide $\mathrm{A}$ to a cyclopropane and subsequent ring opening (Figure 4) (Hoffman and Lindel, 2003).

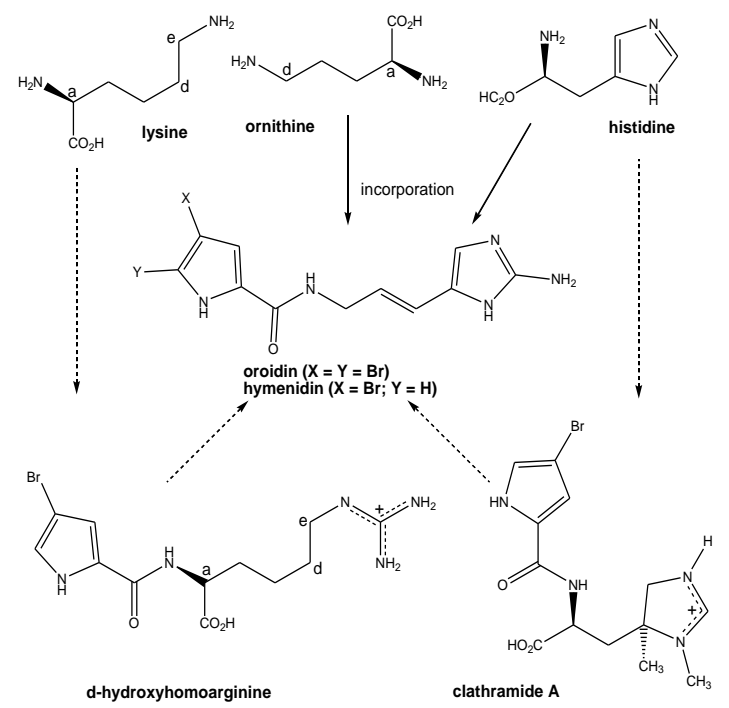

Figure 4. Plausible biosynthetic pathways leading to the key pyrrole-imidazole alkaloid (according to Hoffmann and Lindel, 2003).

Travert and Al-Mourabit (2004) postulated that a pseudo dipeptide pyrroleproline-guanidine is the precursor which leads to the amide-connected $\mathrm{C}_{11} \mathrm{~N}_{5}$ pyrrole and 2-aminoimidazolinone sections (Figure 5). 


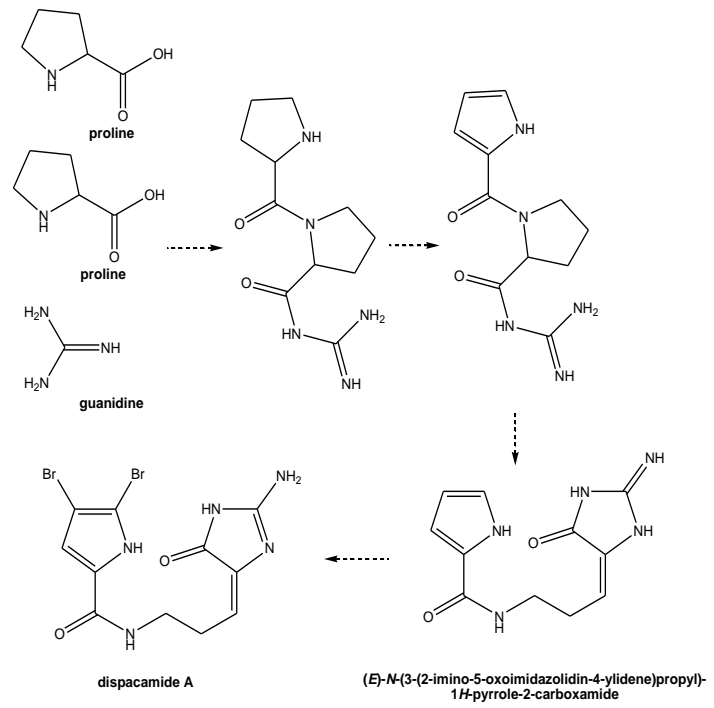

Figure 5. Sequential pyrrole and 2-aminoimidazolinone sections formations (according to Travert and Al-Mourabit, 2004).

First specific step in the pyrrole 2aminoimidazole biosynthesis involves prolinebased peptide synthesis, followed by an oxidation of the proline to pyrrole section and then by an oxidation rearrangement of prolineguanidine moiety to the 2-aminoimidazolinone. Bio mimetic spontaneous conversion study of proline to 2-aminoimidazolinone derivatives suggested dispacamide $\mathrm{A}$ as the forerunner of oroidin. As a consequence of this proposed pathway, 4,5-dibromopyrrole-2-carboxylic acid and 2-amino-5-(3-amino)propylimidazole are probably exist as hydrolysis products and not precursors (Travert and Al-Mourabit, 2004).

Actually, either oroidin or dispacamide A are good candidates as a key metabolite linking the amino acid precursors to the pyrrole 2aminoimidazole family. Moreover, both compounds are frequently found in sponges together with their closely related polycyclic derivatives (Travert and Al-Mourabit, 2004).

Moreover, homoarginine derivatives eventually open the possibility of another alternative biosynthetic pathway of which indicates the existence of a biosynthetic pathway via an open chain intermediate (Assman et al., 1999). Hoffmann and Lindel (2003) proposed that hydroxylation of homoarginine at the $\delta$-position, followed by oxidation and cyclization generates 2aminohomohistidine which then undergoes oxidative decarboxylation and isomerization of the resulting double bond, eventually forms oroidin (Figure 4) (Lindel et al., 2000a). Similar co occurence of homoarginine and 2-amino-3-prop(en)ylimidazoles in the case of the aplysinamisines I and II in Aplysina sp. (Rodriquez and Piña, 1993) and the similar biogenesis pathway of enduracididine, an arginine-derived amino acid which has an imidazoline analogue of aminohistidine in its structure (Horii and Kameda, 1968; Hatano, et al., 1984; Garcia et al., 1996; Hemscheidt et al., 1995) support the above hypothesis (Hoffman and Lindel, 2003).

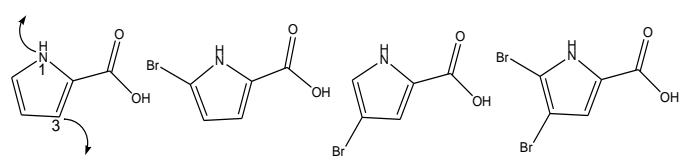

Figure 6. Four building blocks and new nucleophilic positions (N-1 and C-3) (AlMourabit and Potier, 2001)

To explain the high structure diversity of this compound group members, Al Mourabit and Potier (2001) proposed different intra molecular cyclization mechanisms. Positions N1 and $\mathrm{C}-3$ of the pyrrole part participate in intramolecular cyclizations (Figure 6) ( $\mathrm{Al}$ Mourabit and Potier, 2001), while position C-2, which is the most nucleophilic in a free pyrrole has only rarely been quaternized (Hoffmann and Lindel, 2003). Among the simple heterocycles, free or $N$-methylated pyrrole exhibits a relatively strong nucleophicity at C-2 which even rivals nucleophilic solvents (Richard et al., 1998; Mayr et al., 2003; Hoffmann and Lindel, 2003).<smiles></smiles>

Figure 7. The tautomerism and ambivalent reactivity of 2-amino-imidazole (as decribed by Al-Mourabit and Potier, 2001)

The 2-amino-imidazole building block possesses tautomeric property which is important for the molecular diversity of pyrrole-imidazole alkaloids (Figure 7). 


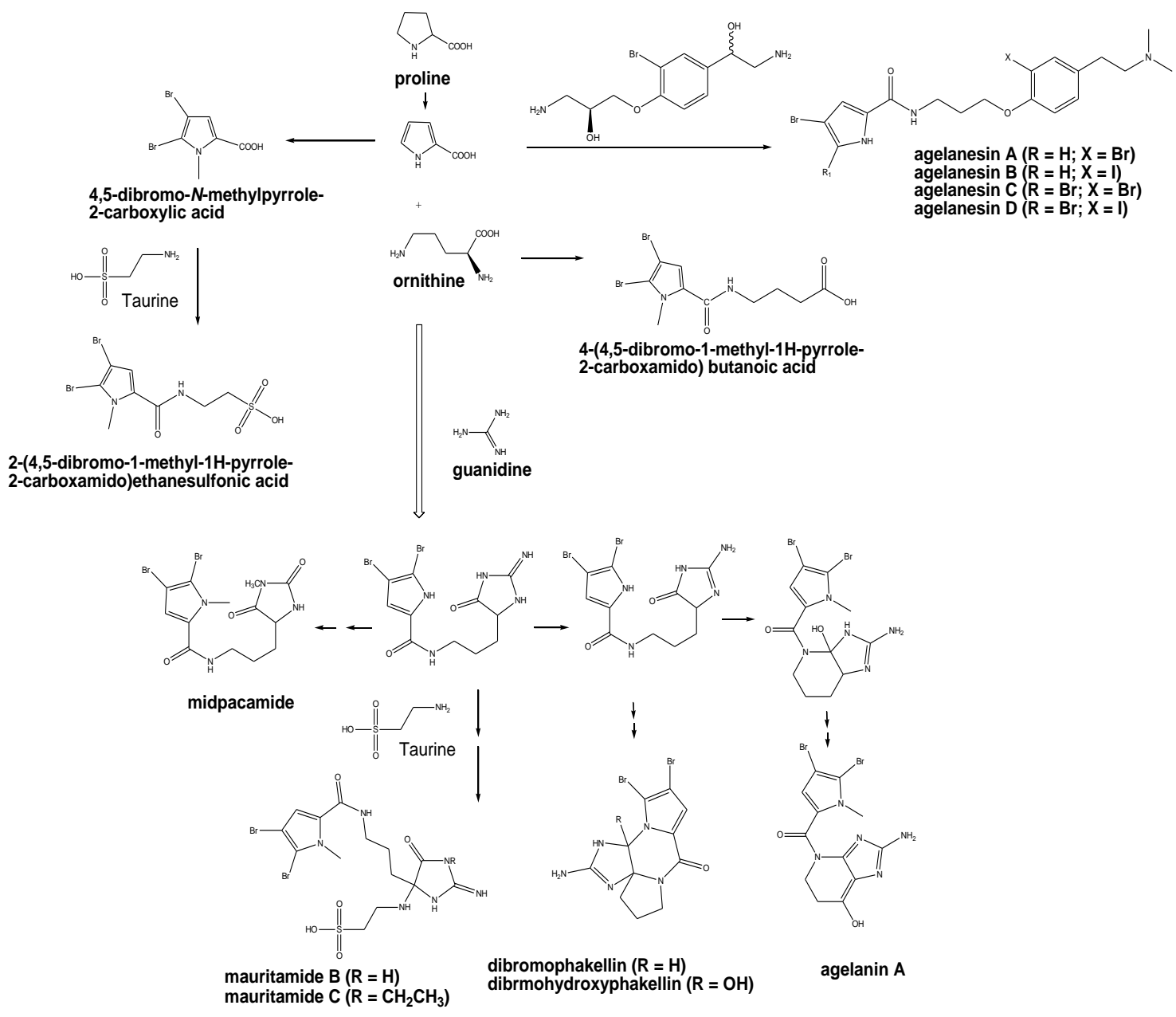

Figure 8. Proposed chemical pathway leading to several A. linnaei metabolites

Each tautomer engaged in this process may act as an initiator of controlled chain reactions leading to various and complex compounds. The tautomerism which can exist simultaneously will give rise to polycyclic metabolites through various combinations with pyrrolic building blocks and diverse modes of cyclization and/or dimerization (Al-Mourabit and Potier, 2001).

Based on the available theory about the pyrrole-imidazole alkaloids biosynthesis, it is more likely that hymenidin is the key building block in their biosynthesis in $A$. nakamurai rather than oroidin. Intermolecular cyclization involving the $\mathrm{N}$-pyrrole and C-9 of this building block leads to compounds like mukanadin C and its new derivative longamide C.
In the case of Seribu Islands sample, $A$. linnaei, beside its possession of more diverse pyrrole-imidazole alkaloids, there are no oroidin or dispacamide as well as homoarginine alkaloids present, whereas some metabolite functionalities is unmatch with the available theory. Midpacamide as the major metabolite together with the co-existence of mauritamides which exhibit relatively similar functional groups in the imidazole ring with a dehydro dispacamide A recommends a putative biosynthetic pathway as described in figure 8 . This pathway may explain the relation of almost all $A$. linnaei metabolites including, midpacamide, mauritamides, agelanin $\mathrm{A}$ as well as the phakellins. 
An involvement of other amino acids such as taurine and tyrosine may also be involved in the diversity of this group of compounds. Mauritamides and N-methyl-4,5dibromopyrrole taurocarboxamide biosynthesis may require taurine as precursor. Meanwhile, tyrosine may involve in the agelanesins biosynthesis through a brominated tyramine related intermediate. Bioconversion pathway of several bromopyrrole alkaloids remains in question. On the other hand, a co-existence of the agelongine alcoholic portion, pyridinebetaine A (Figure 9) in Agelas longissima by Cafieri et al. (1998b) may somehow correlate to the agelongine unusual structure.

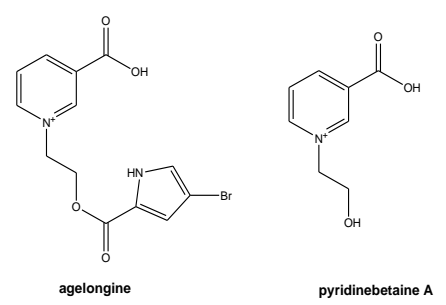

Figure 9. Agelongine and pyridinebetaine A (Cafieri et al., 1998b).

\section{Halogenated pyrroles: Ecology approach towards pharmacology prospects}

Biosynthesis of alkaloids consumes valuable amino acids while efficiency should become a basis consideration for compounds production. It should be an evolutionary advantage for a living organism to generate a maximum degree of molecular diversity and function, on the basis of a common building block. It would be even better, if the building block itself can be part of life saving efforts. Oroidin is a perfect example. This compound has been reported as the chemical weapon of Agelas sponges against predation by reef fishes and in the same time takes part as a key building block of the pyrrole imidazole alkaloids. (Hoffmann and Lindel, 2003). The conservation of brominated pyrrole-imidazole alkaloids as natural products in the tissue of sponges within the genus Agelas suggests that these compounds have been elaborated and retained as part of chemical defenses (Lindel et al., 2000b). From an ecological point of view, the anti-predatory role of oroidin-based alkaloids could be their most important biological function (Assmann et al., 2000; Assmann et al., 2001).

Lindel et al. (2000b) formulated the structure-activity relationship of several oroidin related compounds for feeding deterrent activity. They reported that even though the pyrrole ring is required for the activity, this alone is not sufficient. A dibrominated pyrrole exhibited higher activity in comparison to less brominated analogues. On the other hand, the imidazole moiety is not feeding deterrent on its own, but enhances the activity of the pyrrole ring. A methylation of the $N$-pyrrole, the oxidation state of the imidazole ring at the 4position and the functionalization of the imidazole 2-position were found to give no influence on activity. Removal of the imidazole moiety with retention of the chain resulted in loss of activity, except for the acid. Among the similar, active compounds, increasing polarity appeared to enhance feeding deterrence. This anti feeding assay also revealed an additive effect of the active compounds but no synergy was observed (Lindel et al., 2000b).

Field assays performed by RicheleMaurer et al. (2003) showed that concentration of pyrrole imidazole alkaloids, oroidin and sceptrin in $A$. conifera were unaffected by prolonged protection from fish predators. It is suggested that these compounds were produced possibly at the limit of effectiveness. Wounding induced a three- to four-fold increase production of both compounds and higher amount of these bromopyrroles exuded into the surrounding seawater than normal. This action may prevent further predation as well as protection against invading microorganisms and from fouling (Richele-Maurer et al., 2003). This argument is in accordance with the activity of oroidin and several other bromopyrrole alkaloids against fouling and bacterial infection (Tsukamoto et al., 1998). The strategy to enhance production of bioactive compounds in response to environmental changes would optimize fitness. Defence are known to be costly, while energy is needed for other functions such as growth and reproduction (Schupp et al., 1999; RicheleMaurer et al., 2003). 
An attempt to translate the result of the ecological function of the halogenated pyrroles reveals possible development of this compound group as drug lead. Based on the assumption that effect of calcium influx and calcium levels in neurons, secretory cells may be related to the feeding deterrence through smell and taste, Bickmeyer et al. (2004; 2005) performed an experiment to observe the effect of several bromopyrrole alkaloids on calcium levels in PC12 cells (rat phaeochromocytoma cell line). It was reported that unpalatable 4,5dibromopyrrole-2-carboxylic acid against predatory reef fish is not (only) transduced by specific membrane receptors present on sensory nerve cells but (additionally) has a more general pharmacological effect on the cellular calcium homeostasis (Bickmeyer et al., 2004).

Basically, chemo-receptive cells are exposed to the environment, and cellular signalling may be modulated by substances interacting with the basic physiology of the cell, but not necessarily by binding to specific taste receptors (Bickmeyer et al., 2004, 2005). As the same mechanism may work in sensory cells of predatory fishes and other animals like snails the inhibition of $\mathrm{Ca}^{2+}$ influx into receptor cells may be one reason for chemoreceptive detection (Bickmeyer et al., 2004, 2005). In harmony with the ecological point of view, blockade on calcium entry may be pharmacologically important since it can induce vasorelaxation as obseved in many hypertensiondrugs (Bickmeyer et al., 2004).

Midpacamide is the major constituent of the $A$. linnaei $(1.01 \%$ of sponge dried weight) (Hertiani et al., 2010). It is a dibrominated pyrrole having a $N$-methylated hydantoin ring connected through a propylamide chain. According to Lindel and collaborators (2000b), this compound is the most potent as feeding deterrent in comparison to the other six pyrrole imidazole alkaloids tested, 4,5-dibrompyrole carboxamide, 4,5-dibromopyrrole-2-carboxylic acid, oroidin, keramadine dispacamide and racemic longamide $\mathrm{A}$. Based on this finding accompanied with its predominance in the sponge, it is likely to assume that midpacamide functions as the main chemical weapon of $A$. linnaei against its predators.

Relatively high structure diversity and predominance of the pyrrole-imidazole alkaloids in $A$. linnaei may be due to their function as chemical defense for the host sponge in order to provide broader spectrum of protection. Midpacamide, as a main feeding deterrent (Lindel et al., 2000b) displays moderate cytotoxicity against mouse lymphoma cell L5178Y (46.7\% inhibition in $10 \mu \mathrm{g} / \mathrm{mL}$ sample concentration) and only low antibacterial activity against B. subtilis. The role of cytotoxic activity as well as antimicrobial and antifouling activity is presumably taken by other metabolites.

A different finding was observed in $A$. nakamurai which relies more on their diterpene alkaloids but not pyrrole-imidazole compounds for chemical defences. Considering that these diterpenoids play a major role in sponge defense may answer to the less diverse production of pyrrole-imidazole alkaloids in this sponge. Among the pyrrole-imidazole metabolites, 4-bromo- $1 H$-pyrrole-2-carboxylic acid and hymenidin are discovered to be predominating. From their structure one can predict that these compounds contribute in the feeding deterrent mechanism of the sponge producer, together with the other congener, 4bromo-1H-pyrrole-2-carboxamide.

More literatures on the oroidin derivates bioactivity were reports on biofilm inhibition effects (Richards et al., 2008a, 2008b, 2008c, 2008d, 2008e; Ballard et al., 200; Huigens et al., 2007) This effect has been proposed to be in correlation with the sponge's antifouling defense mechanism (Hertiani, 2008). Sponges as filterfeeder organisms need to be free of fouling in order to pump water and nutrition. Therefore, a chemical defense in form of antifouling compounds can be one powerful strategy. Never-theless a research done on several oroidin related from $A$. linnaei showed no inhibition on biofilm formation of $S$. epidermidis by in vitro method (Hertiani, 2008). This activity was reported from other type of compounds isolated from $A$. nakamurai, the (-)-Ageloxime (Hertiani etal., 2010; Hertiani, 2008). Considering that biofilm associated micobes have great significance for public health, since they may cause a dramatical decrease in susceptibility towards antimicrobial agents (Donlan, 2001). Finding a potential biofilm inhibitor is therefore of interest in combating infection especially in immunesuppressed condition. 


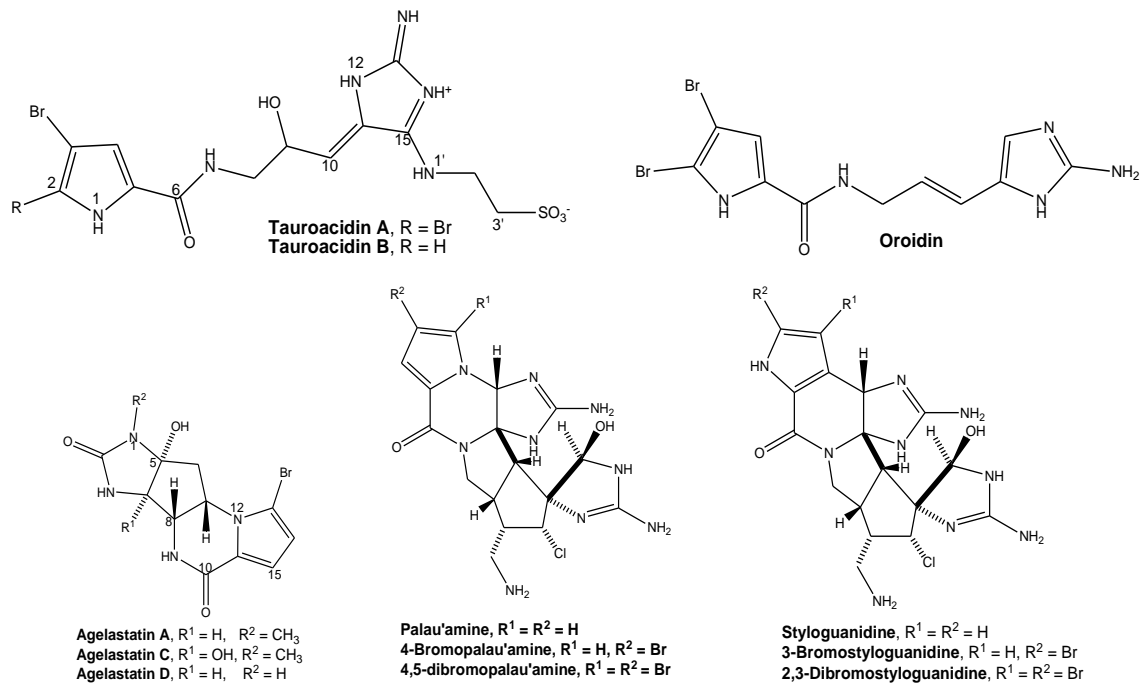

Figure 10. Some bioactive halogenated-pyrrole derivatives from sponges.

Agelastatins (Figure 10) is probably the most important pyrrole-imidazole alkaloids isolated from Agelas sponges. These compounds have a unique fused tetracyclic skeleton which may formally be derived from an open chain pyrroloaminopropylimidazole precursor similar in structure to oroidin (Whitehead, 1999). In 1998, Hong et al. reported the isolation of the known Agelastatin A together with two new alkaloids, Agelastatins $\mathrm{C}$ and $\mathrm{D}$ from a West Australian sponge Cymbastela sp. (Axinellidae). Agelastatin A was highly toxic to brine shrimp with $\mathrm{LC}_{50}$ of 1.7 ppm $(5.0 \mu \mathrm{M})$ whereas Agelastatin $\mathrm{C}$ was much less toxic with $\mathrm{LC}_{50}$ of $\sim 220 \mathrm{ppm}$. Insecticidal activity of Agelastatin A was reported to be comparable to a commercial preparation of the biopesticide Bacillus thuringiensis (Hong et al., 1998; Whitehead, 1999).

Agelastatin A was reported to exhibit significant cytotoxicity towards many types of cancer cell lines (D'Ambrosio et al., 1993; 1996; Meijer et al., 2000; Pettit et al., 2005). This compound inhibited tumor cell growth from 1.5 to 16 times more potently than cisplatin, particularly, against human bladder, skin, colon, and breast carcinomas (Hale et al., 2005). Moreover, Agelastatin A was demonstrated to be very effective in down-regulating the expression of $\beta$-catenin and in up-regulating Tcf-4, an inhibitor of osteopontin (OPN) at the cellular level. These two effects result in repression of OPN and inhibition of OPNmediated malignant cell invasion, adhesion, and colony formation in vitro (Mason et al., 2008). Longley also highlighted the ability of this compound in inhibiting $\beta$-catenin, which controls transcription of multidrug resistance (Longley and Johnston, 2005). Therefore, it could be helpful in reducing drug resistance issues, possibly both as single agent as well as in combination therapy (Forte et al., 2009). Hale and collaborators reported that agelastatin A was also exhibited inhibition activity towards glycogen synthase kinase-3 $\beta$ (GSK-3 $\beta$ ), an enzyme responsible for the neurofibrillary tangles typically found in Alzheimer's disease, and as a mimetic of insulin (Hale et al., 2003).

The Palau'amines (Figure 10) is another series of complex, halogen containing alkaloids belonging to oroidin family. These compounds exhibit six contiguous rings and an unbroken chain having eight chiral centers (Whitehead, 1999). Palau'amine and its 4-bromo and 4,5dibromo derivatives were isolated in 1998 Kinnel et al. together with three previously reported ring A regioisomers (styloguanidines), from the sponge Stylotella aurantium. Palau'amine itself was reported to display a remarkable range of biological activities having an $\mathrm{IC}_{50}$ value of less than $18 \mathrm{ngml}^{-1}$ in the mixed lymphocyte reaction, and values of $\mathrm{IC}_{50}$ of 0.1 and $0.2 \mu \mathrm{g} / \mathrm{mL}^{-1}$ against P-3888 and A-549 cel lines, respectively (Whitehead, 1999). 


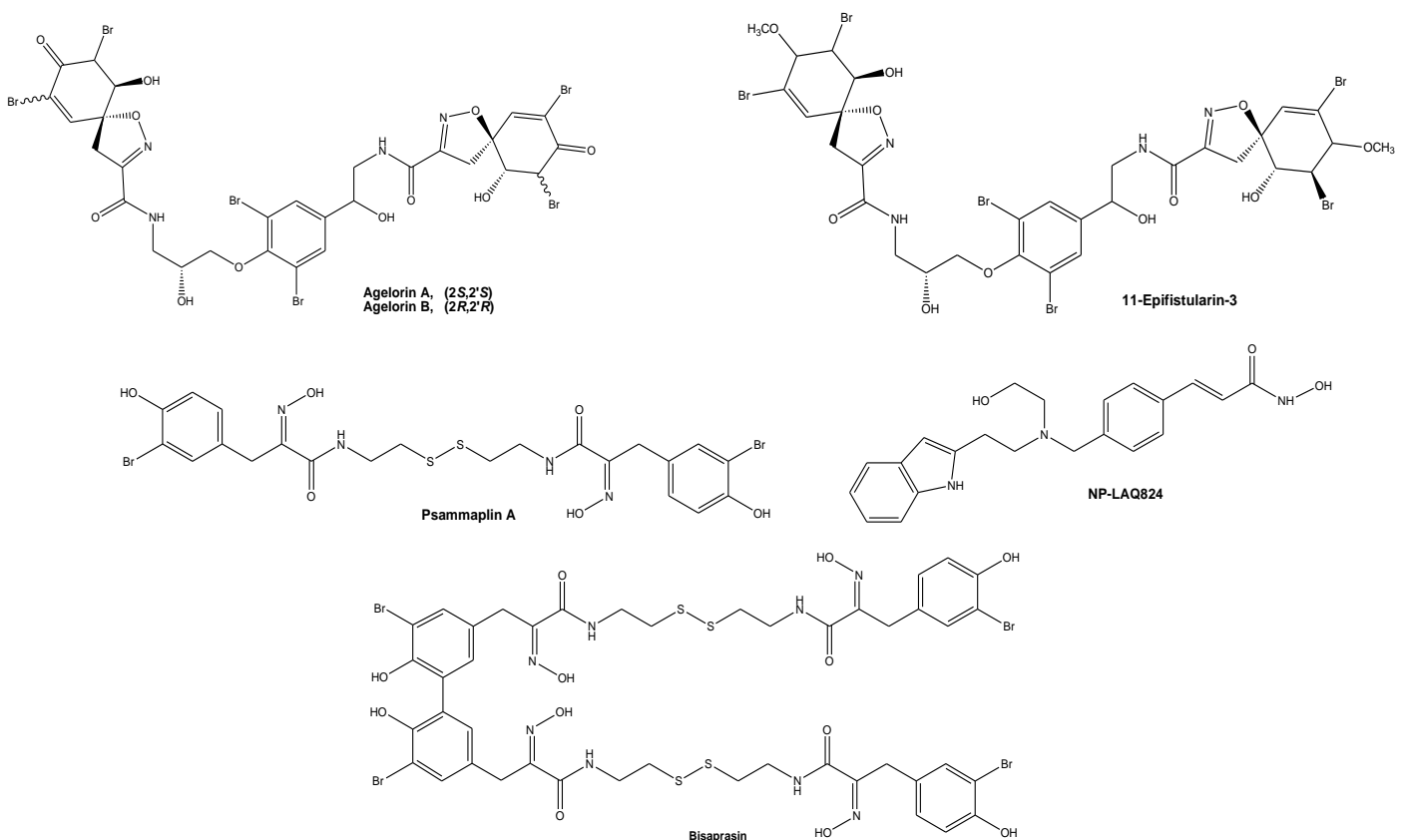

Figure 11. Some bioactive bromotyrosine-derived metabolites found in sponges

The preclinical studies of this compound are currently in progress for anti-fungal, anti-tumor and immunosuppressive agent (Kinnel et al., 1998; Whitehead, 1999).

Tauroacidins A and B (Figure 10), two novel taurine-residue-containing bromopyrrole alkaloids which were isolated from an Okinawan sponge Hymeniacidon sp. (Figure 12) (Kobayashi et al., 1997). Both alkaloids were reported to show inhibitory activity against EGF receptor kinase and c-erb B-2 kinase $\left(\mathrm{IC}_{50}\right.$, $20 \mu \mathrm{g} / \mathrm{mL}^{-1}$ each) (Kobayashi et al., 1997). Three other novel taurine derived brompyrrole alkaloids isolated from $A$. linnaei, Mauritamide B, C and 2-(4,5-dibromo-1-methyl-1H-pyrrole2-carboxamido)ethanesulfonic acid (Figure 9), exhibited no inhibition on the protein kinases (Hertiani, 2007).

Other report from Scala et al. (2010) exhibit the potency of bromopyrrole alkaloids as a potential drug lead for anti protozoa. Dispacamide $\mathrm{B}$ and spongiacidin $\mathrm{B}$ were reported as a potential antimalarial and can be developed as drug lead based on the result that these compounds showing significant activity with low or no toxicity towards mammalian cells (L6). Moreover, Scala et al. (2010) also described dibromopalau'amine and longamide $B$ potency as trypanocidal and antileishmanial agents, with narrow therapeutic windows. Number of bromine substitution on the pyrrole carbon was reported to be important for the antiplasmodial activity (Tasdemir et al., 2007), which was also observed in the activity towards T. brucei rhodiense and Leishmania (Scala et al., 2010). The imidazol type ring was suggested to be of important for antimalarial activity (Scala et al., 2010).

\section{Tyrosine derived brominated compounds from A. linnaei}

Other important halogen containing secondary metabolites from sponges are the brominated compounds biogenetically related to tyrosine (Figure 11). Although this group of compounds is more likely to be found in Verongid sponges (Hamman et al., 1993; Tabudravu and Jaspars, 2002), nevertheless, König and Wright (1993) have reported the isolation of bromotyrosine-derived alkaloids (Agelorins A and B, and 11-Epifistularin-3) from Agelas oroides.

Psammaplin A, a symmetrical bromotyrosine disulfide possessing oxime moieties isolated from Verongid sponges, was found to have potent cytotoxicity to P 388 cells $\left(\mathrm{IC}_{50}\right.$ of $\left.0.3 \mu \mathrm{g} / \mathrm{mL}^{-1}\right)$. Its dimeric metabolite, bisaprasin was also occured in the sponge producer 

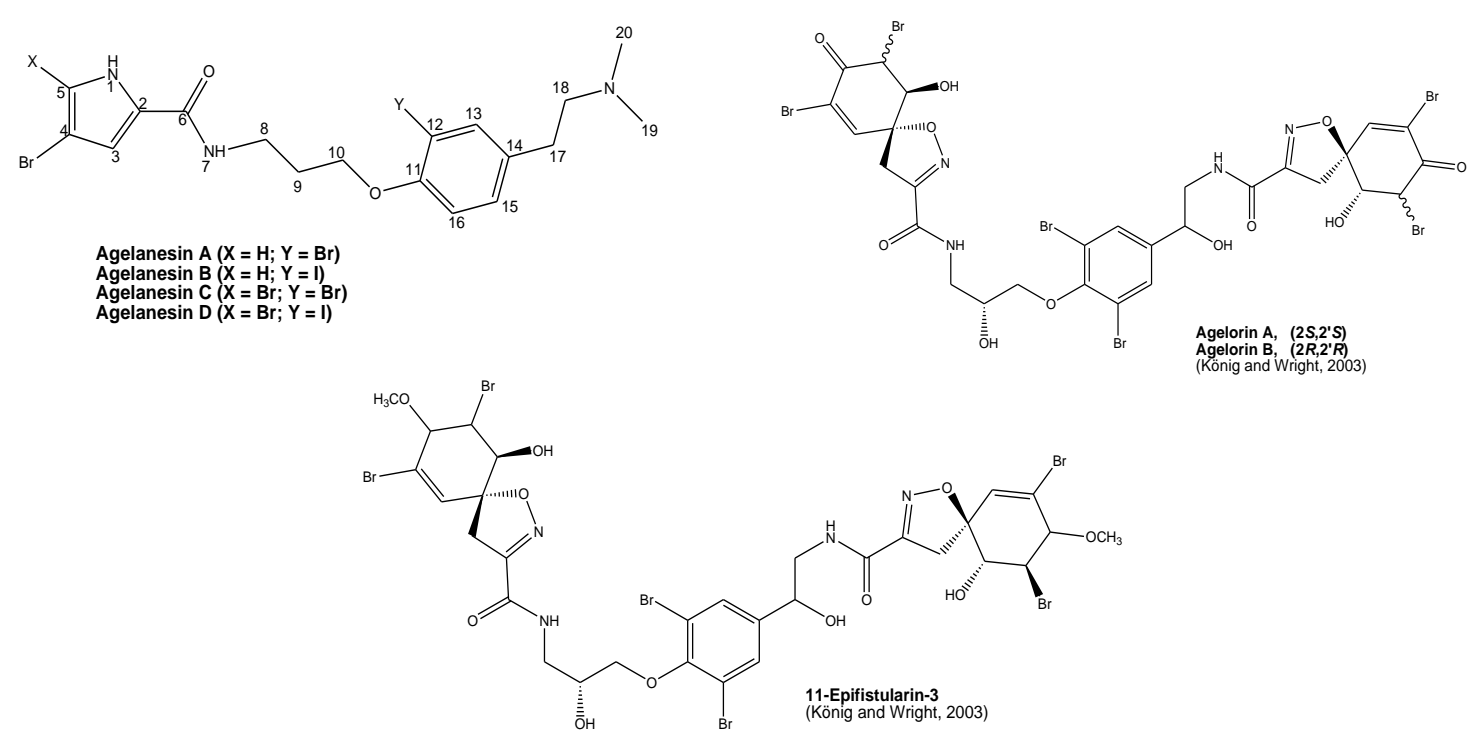

Figure 12. Chemical structures of tyrosine-derived brominated compounds from Agelas oroides (König and Wright, 1993) and from A. linnaei (agelanesin A-D) (Hertiani et al., 2010)

(Arabshahi and Schmitz, 1987; Quiñoà and Crews, 1987; Rodriquez et al., 1987). The fact that the psammaplins have been isolated from a diversity of sponge "sources" and that brominated aromatic amino acid derivatives are common in marine bacteria suggest that these metabolites may actually be produced as a collaborative work between the sponge host and the associated microorganisms (Simmons $e t$ al., 2005).

Both psammaplin A and bisaprasin were reported as DNA methyl transferase and histone deacetylase inhibitors (Pina et al., 2003). This is an interesting finding considering the potential relationship between DNA methyl transferase and histone deacetylase as epigenetic modifiers of tumor suppressor gene activity (Pina et al., 2003). Furthermore, psammaplin A has also been reported to inhibit topoisomerase II (Kim et al., 1999) and aminopeptidase $\mathrm{N}$ with in vitro angiogenesis suppression (Shim et al., 2004).

Four new brominated pyrrole derivatives connected to a halogenated tyramine unit were obtained from A. linnaei (Hertiani et al., 2010). Halogenated tyrosine-derived metabolites are actually more likely to be found in Verongid sponges, although they were also reported from several others (Constantino et al., 1994; König and Wright, 1993). Agelorin A and B as well as 11-epi-fistularin-3 are other known tyrosinerelated representatives from the marine sponge genus Agelas (König and Wright, 1993).

The presence of a halogenated tyramine moiety linked to a brominated pyrrole unit has never been reported before from natural products. Replacement of the brominated tyramine moiety in agelanesin $\mathrm{A}$ and agelanesin $\mathrm{C}$ with iodinated tyramine in agelanesin $\mathrm{B}$ and agelanesin $\mathrm{D}$ attract attention to this group of compounds.

It is very challenging to find out why this Agelas sponge incorporated iodine into the agelanesins to substitute the bromine. Iodoalkaloids are known to be very rare natural products which are until now only isolated from marine organisms, (Gribble, 1996a, 1996b, 1998, 2000; Faulkner, 1995) more specifically from very few algae and sponges (Niedleman and Geigert, 1986; Constantino et al., 1994). Iodide availability in sea water is far below other halogens such as bromide and chloride.

Despite its low concentration, unlike chloride, all known haloperoxidases are effective in oxidizing iodide (Niedleman and Geigert, 1986). According to Constantino et al. (1994), biosynthesis of iodinated metabolites seems to be related to the capability of organisms to concentrate iodine from sea 
water, rather than to the presence of a specific peroxidase. This argument was based on the fact that most iodo-metabolites have been isolated from red algae, which are known to contain iodine concentrations as high as $0.5 \%$ of weight wt (Constantino et al., 1994). An iodotyrosine alkaloids sponge producer, Iotrochota birotulata was reported to contain significant amounts of iodine (0.12-1.21\%), together with comparable quantities of bromine (0.16-2.66\%) (Kaestner, 1967). Hence this supports the relationship between the presence of iodo- metabolites and high concentration of iodine in the sponge tissue (Constantino et al., 1994).

Another question arising from the agelanesins unique structure is their biosynthesis. As described earlier, pyrrole imidazole family of compounds such as oroidin and sceptrin are predicted to be produced by sponge cells and not by the associated bacteria (Richele-Maurer, 2003). Meanwhile Simmons and collaborators (2005) proposed that the brominated tyrosine metabolites may actually be derived from the biosynthetic pathway of microorganisms living in association with sponges. It is therefore more likely that in case of the agelanesins, the brominated pyrrole 2 carboxylic acids are produced by the sponge cell at first, and further converted by associated bacteria to afford agelanesins.

In addition to its unique chemical structure, this group of compounds also showed interesting bioactivity. Agelanesin A $\mathrm{D}$ showed cytotoxicity against the mouse lymphoma cell line (L1578Y) with $\mathrm{IC}_{50}$ value $4.5 \mu \mathrm{g} / \mathrm{mL} ; \quad 4.8 \mu \mathrm{g} / \mathrm{mL} ; \quad 9.2 \mu \mathrm{g} / \mathrm{mL} ; \quad$ and $7.8 \mu \mathrm{g} / \mathrm{mL}$ respectively. In comparison to other brominated pyrroles isolated from $A$. linnaei, only this group of compounds shows pronounced cytotoxicity (Hertiani et al., 2010). At the same time, aplysamine- 2 and aeroplysinin-1, obtained from Pseudoceratina purpurea exhibits the same activity as well. Some other brominated tyrosine compounds have also been previously reported to be cytotoxic such as psammaplin A and bisaprasin (Arabshahi and Schmitz, 1987; Quiñoà and Crews, 1987; Rodriquez et al., 1987). Hence it is suggestive that the halotyramine moiety of agelanesin A-D is important for the activity (Hertiani et al., 2010).

Based on the $\mathrm{IC}_{50}$ values of the agelanesines against mouse lymphoma cell line (L5178Y), a possible structure activity relationship is suggested. Since the highest activity was shown by agelanesin $\mathrm{A}$ followed by agelanesin B, D and C, respectively, less bromination on the pyrrole ring seems to be important for the activity (Hertiani et al., 2010). This is somehow in contrast to the result of feeding deterrent activity reported by Lindel $e t$ al., 2000b, since higher degree of the bromination in the pyrrole ring will increase the activity (Lindel et al., 2000b). Meanwhile, different halogen atom attached to the tyramine unit (C-12) causes only slight difference on the cytotoxicity (Hertiani et al., 2010).

\section{Synthesis approach: an alternative for continuous supply}

One of the most important requirement of a natural product being developed as medicine or drug lead, it should be obtained by a continuous supply. Despite being a promising lead for many medicinal purposes, halogenated alkaloids in Agelas sponges have been postulated to be originated from sponge cell itself and not from its symbiont (RichelleMaurer et al., 2003). This fact has closed the posibility of obtaining these alkaloids through cultivation of the endophytes/symbionts as one possible alternative in obtaining marine metabolites with more eco-friendly approach.

Mariculture is one approach in effort to provide continuous supply by cultivating sponge in its environment. This approach has advantages as cultivation can be managed in its natural condition and may be expected to produce compound of interest. Nevertheless $A$. nakamurai collected from Menjangan Island in different collection time, resulted different chemical constituents as reported by Hertiani and collaborators (2010) and Murti (2006). Another report by Eder and collaborators (1999) reported dimers, i.e., Sceptrin, Debromosceptrin, Ageliferin, Nakamuric acid and its methyl ester derivate. A. nakamurai from Okinawa has been reported to produce other constituents as well as the sponge 
collected from Papua New Guinea (Iwagawa et al., 1998). Eventhough the above finding can be due to different isolation procedures applied for each research groups, further evaluation should be done in order to define the best cultivation as well as isolation procedure of the target compounds.

Several of promising halogenated alkaloids from Agelas have been successfully synthesized in laboratory. One interesting example is the Agelastatins. These natural products share a complicated tetracyclic core having four stereocenters, which is a synthetically challenging structure. The impressive biological activity, following its scarce availability have triggered the total synthesis attempts for these contriguing substance. Fifteen total syntheses have been achieved for this compound, each presenting different strategies (Kitagawa et al., 1983; Stien et al., 1999; Feldman et al., 2002; Feldman et al., 2002; Domostoj et al., 2004; Davis and Deng, 2005; Nicolaou et al., 2000).

Ageladine A which is 4-(4,5-dibromo1H-pyrrol-2-yl)]-1H-imidazo[4,5-c]pyridin-2-

amine has been reported to be successfully synthesized through a 12-step total synthesis by using a $6 \pi$-azaelectrocyclization and a Suzuki-Miyaura coupling of N-Boc-pyrrole-2boronic acid of which a chloropyridine roles as key step (Meketa and Weinreb, 2006). Ageladin A has been reported as a potential antiangiogenic matrixmetalloproteinase inhibitor isolated from A. nakamurai (Fujita et al., 2003)

Eventhough (Z)-hymenialdisine [(Z)HMD s not derived form Agelas sponge, its worth to be discussed here considering its properties as the only pyrrole imidazole alkaloids being potential kinase inhibitor. As it showed nanomolar kinase inhibitory activity against pan-kinases (Meijer et al., 2000), it is potentially useful not only for the treatment of cancer, but also for neurodegenerative disorders as Alzheimer's, inflammatory pathologies, type2 diabetes and cancer.

Synthetic approaches (Annoura et al., 1995; Xu et al., 1997, Sosa et al., 2000, Portevin et al., 2003; Papeo et al., 2005) towards $(Z)$-HMD have beenreported to produce multrigrams of yield. 1-Benzoyl-2-methylsulfanyl-1,5-dihydroimidazol-4-one employed in Papeo's approach was also useful in the first total synthesis of $(Z)$-axinohydantoin. Different series of analogues were synthesized (He et al., 2007; Chacun-Lefevre et al., 2000; Wan et al., 2004). Those derivatives left the main features of (Z)-HMD binding site in the kinase ATP unchanged. Efforts have been made to improve its selectivity and permeability (Kaiser et al., 2007; Mangu et al., 2008; Parmentier et al., 2009).

Psammaplin A, is a promising anti cancer candidate isolated from Verongid sponges. This compound has close structure relationship with the halogenated tyrosine derived alkaloids from Agelas sponges. This compounds has been developed as a drug lead of which its analogue substance, NP-LAQ824 (Remiszewski, 2003), has recently entered phase I clinical trials in patients with solid tumors or leukemia (Simmons et al., 2005).

The susccess of producing oroidin derivatives by several approach (Fresneda et al., 2001; Lindel and Hoffmann, 1997; Olofson et al., 1998; Sun and Chen, 2007; Ando et al., 2006) have offer more possibility of producing antiprotozoal compounds which are closely related to this compounds as described by Scala et al. (2010) by a synthetic route. The synthesis of the oroidin itself has been reported in many literatures (as reviewed in Forte et al., 2009). The method by Richards et al. (2008e) offers a possibility of producing the synthetic derivates related to this groups of compound for antibiofilm activity against $P$. aeruginosa.

A synthetic approach opens many doors for these compounds to be developed as drug lead. Their presence as a highly diverse group of compounds has offered new possibilities for utilization as medicinal purposes. As we know that marine sponge metabolites face difficulties to be developed as drug as it needs tremendous amount and a continuous supply, a possiblity of having these compounds syntheized in the laboratory is relieving.

\section{CONCLUSION}

Halogenated alkaloids are marine sponge specific which offers a tremendous and unique structure diversity. These metabolites play significant role for their sponge producers and at the same time take part in the ecological aspects. Many halogenated alkaloids including 
those found in Agelas sponges exhibit promising activity to be developed for medicinal purposes. Despite being spongeoriginated-metabolites, which put big question mark on their continuous supply has not stop its development. Many efforts have resulted succesful production of selective metabolites through chemical synthesis, and many more analogues were created for better activity or bioavailability to fulfill the needs for new drug from the deep.

\section{ACKNOWLEDGEMENT}

Author thank Prof. Peter Proksch (Heinrich-Heine Universiteit, Duesseldorf, Germany) and to Dr. RuAngelie Edrada-Ebel for valuable support on the manuscript preparation.

\section{REFERENCES}

Ahond A., Zurita MB., Colin M., Fizames C., Laboute F., Laurent D., Poupat C., Pusset J., Thoison M., Potier P., 1998, La girolline, nouvelle substance antitumoraJe extraite de I'eponge Pseudaxlnyssa cantharella n.Sp., C.R. Acad. Paris, 307, 145-148

Al Mourabit A., Potier P., 2001, Sponge's Molecular Diversity Through the Ambivalent Reactivity of 2Aminoimidazole: A Universal Chemical Pathway to the Oroidin-Based PyrroleImidazole Alkaloids and Their Palau'amine Congeners, Eur. J. Org. Chem., $237-243$

Amador ML., Jimeno J., Paz-Ares L., CortesFunes H., Hidalgo M., 2003, Progress in the development and acquisition of anticancer agents from marine sources, Ann. Oncol., 14, 1607-1615

Ando N., Terashima S. 2006, A novel synthesis of the 2-aminoimidazol-4-carbaldehyde derivatives, versatile synthetic intermediates for 2-aminoimidazole alkaloids. Synlett 2836-2840.

Andrade P., Willoughby R., Pomponi SA., Kerr RG., 1999, Biosynthetic Studies of the Alkaloid, Stevensine, in a Cell Culture of the Marine Sponge Teichaxinella morchella Tetrahedron Lett., 40, 4775-4778

Annoura H., Tatsuoka T. 1995, Total syntheses of hymenialdisine and debromohymenialdisine: Stereospecific construction of the 2-amino-4-oxo-2imidazolin-5(Z)-disubstituted ylidene ring system. Tetrahedron Lett. 36, 413416.

Arabshahi L., Schmitz FJ., Brominated tyrosine metabolites from an unidentified sponge, J. Org. Chem., 1987, 52, 3584-3586

Assmann M., Van Soest RWM., Köck M., 2001, New antifeedant bromopyrrole alkaloid from the Caribbean sponge Stylissa caribica, J. Nat. Prod., 64, 13451347

Assmann M., Lichte E., Pawlik JR., Köck M., 2000, Chemical defenses of the Caribbean sponges Agelas wiedenmayeri and Agelas conifera, Mar. Ecol. Prog. Ser., 207, $255-262$

Baker Z., 2004, Isolation and Structure Elucidation of Bioactive Secondary Metabolites from Marine Sponges and Tunicates, Dissertation, Heinrich-Heine Universität, Düsseldorf

Ballantyne JS., Storey KB., 1983. Mitochondria from the ventricle of the marine clam, Mercenaria mercenaria: substrate preferences and effect of $\mathrm{pH}$ and salt concentration on proline oxidation, Comp. Biochem. Physiol., 76B, 133-138

Ballard TE., Richards JJ., Wolfe AL., Melander C. 2008, Synthesis and antibiofilm activity of asecond-generation reverseamide oroidin library: A structureactivity relationship study. Chem. Eur. J. 14, 10745-10761.

Bergmann W., Feeney RJ., 1951, Contributions to the study of marine products. XXXII. The nucleosides of sponges. J.O.C.,16, $981-987$

Bergmann W., Feeney RJ., 1950, The isolation of a new thymine pentoside from sponges J. Am. Chem. Soc., 72, 2809

Bickmeyer U., Drechsler C., Köck M., Assmann M., 2004, Brominated pyrrole alkaloids from marine Agelas sponges reduce depolarization-induced cellular calcium elevation, Toxicon, 44, 45 - 51

Bickmeyer U., Assmann M., Köck M., Schütt C., 2005, Bromoageliferin and dibromoageliferin, secondary metabolites from the marine sponge Agelas conifera, 
inhibit voltage-operated, but not storeoperated calcium entry in PC12 cells, Environt. Toxicol. Pharmacol., 19, 423 - 427

Blunt JW., Copp BR., Munro MHG., Northcote PT., aPrinsep MR., 2005. Marine natural products. Nat. Prod. Rep., 22, $15-61$

Braekman JC., Daloze D., Stoller C., Van Soest RWM., 1992, Chemotaxonomy of Agelas (Porifera: Demospongiae), Biochem. Syst. Ecol., 20 (5), 417-431

Cafieri F., Fattorusso E., Taglialatela-Scafati O., 1998a. Novel bromopyrrole alkaloids from the sponge Agelas dispar. J. Nat. Prod., 61, 122-5

Cafieri F., Fattorusso E., Taglialatela-Scafati O., 1998b. Novel betaines from the marine sponge Agelas dispar. J. Nat. Prod., 61, 1171-1173

Cafieri F., Fattorusso E., Mangoni A., Taglialatela-Scafati O., 1996, Clathramides, Unique Bromopyrrole Alkaloids From the Caribbean Sponge Agelas clathrodes Tetrabedron, 52, 13713

Cafieri F., Fattorusso E., Mangoni A., Taglialatela-Scafati O., 1995, Bioorg. Med. Chem. Lett., 5, 799-804

Carte BK., 1993. Marine natural products as a source of novel pharmacological agents, Curr. Opin. Biotechnol., 4(3),275-279

Chacun-Lefevre L., Joseph B., Merour JY., 2000, Synthesis and reactivity of azepino[3,4-b]indol-5-yl

trifluoromethanesulfonate. Tetrahedron, 56, 4491-4499.

Christian MC., Pluda JM., Ho PT., 1997. Promising new agents under development by the Division of Cancer Treatment, Diagnosis, and Centers of the National Cancer Institute, Semin. Oncol., 24, 219-240

Costantino V., Fattorusso E., Mangoni, A., 1994. Three New Brominated and Iodinated Tyrosine Derivatives from Iotrochota birotulata, a Non-Verongida Sponge, J. Nat. Prod., Vol. 57, No.11, $1552-1556$

Davis FA., Deng J. 2005, Asymmetric total synthesis of (-)-agelastatin A using sulfinimine (Nsulfinylimine) derived methodologies. Org. Lett., 7, 621-623.
D'Ambrosio M., Guerriero A., Debitus C., Ribes O., Pusset J., Leroy S., Pietra F., 1993, Agelastatin A, a new skeleton cytotoxic alkaloid of the oroidin family. Isolation from the axinellid sponge Agelas dendromorpha of the Coral sea. J. Chem. Soc., Chem. Commun.1305-1306.

D'Ambrosio M., Guerriero A., Ripamonti M., Debitus C., Waikedre J., Pietra F. 1996, The active centers of agelastatin A, a strongly cytotoxic alkaloid of the Coral Sea axinellid sponge Agelas dendromorpha, as determined by comparative bioassays with semisynthetic derivatives. Helv. Chim. Acta, 79, 727-735.

Dembitsky VM., Tolstikov GA., 2003. Natural Halogenated Alkaloids. Chemistry for Sustainable Development, 11, 451-466

Domostoj MM., Irving E., Scheinmann F., Hale KJ. 2004, New total synthesis of the marine antitumor alkaloid (-)agelastatin A. Org. Lett. 6, 2615-2618.

Edrada RA., Wray V., Handayani D., Schupp P., Balbin-Oliveros M., Proksch P., 2000, Structure-activity relationships of bioactive metabolites from some IndoPacific marine invertebrates. In: Atta-urRahman (ed.) Studies in natural products chemistry, Vol 21. Elsevier, Amsterdam, 251-292

Eder C., Proksch P., Wray V., van Soest RW., Ferdinandud E., Pattisina LA., Sudarsono, 1999, New bromopyrole alkaloids from the Indopacific sponge Agelas nakamurai, J. Nat. Prod. 62(9): 1295-7

Faulkner DJ., 2002, Marine natural products, Nat. Prod. Rep., 19, 1-48

Faulkner DJ., 2001, Marine natural products, Nat. Prod. Rep., 18, 1-49

Faulkner DJ., 2000, Marine natural products, Nat. Prod. Rep., 17, 7-55

Faulkner DJ., 1995, Marine natural products, Nat. Prod. Rep., 12, 223-269

Faulkner DJ., Andersen RJ., The Sea, 1974, Vol. 5, Wiley, New York, London, Sydney, and Toronto, 679-714

Fedoreyev SA., Ilyin SG., Utkina NK., Maximov OB., Reshetnyak MV., Antipin MY., Struchkov YT., 1989, The structure of dibromoagelaspongin - A novel 
bromine-containing guanidine derivative from the marine sponge Agelas sp, Tetrahedron, 45(11), 3487-3492

Feldman KS., Saunders JC. 2002, Alkynyliodonium salts in organic synthesis. Application to the total synthesis of (-)-agelastatin A and (-)agelastatin B. J. Am. Chem. Soc. 124, 9060-9061.

Feldman KS., Saunders JC., Wrobleski ML., 2002, Alkynyliodonium salts in organic synthesis. Development of a unified strategy for the syntheses of (-)agelastatin A and (-)-agelastatin B. J. Org. Chem. 67, 7096-7109.

Forte B., Malgesini B., Piutti C., Quartieri F., Scolaro A., Papeo G., 2009, A Submarine Journey: The PyrroleImidazole Alkaloids, Mar. Drugs 7, 705753; doi:10.3390/md7040705

Fresneda PM., Molina P. Sanz MA., 2001, A convergent approach to midpacamide and dispacamide pyrrole-imidazole marine alkaloids. Tetrahedron Lett. 42, 851-854. 31.

Fujita M., Nakao Y., Matsunaga S., Seiki M., Itoh Y., Yamashita J., van Soest RWM., Fusettani N., 2003, Ageladine A: an antiangiogenic matrixmetalloproteinase inhibitor from the marine sponge Agelas nakamurai, $J$ Am Chem Soc. Dec 24;125(51):15700-1.

Garcia, A., Vazquez, M.J., Quiñoa, E., Riguera, R., and Debitus, C., 1996, New amino acid derivatives from the marine Ascidian Leptoclinides dubius, J. Nat. Prod., 59, 782

Gribble GW., Natural organohalogens, 2004, Eurochlor, Brussels, 11-13, 29

Gribble GW., The Natural production of organobromine compounds, Environ. Sci. Pollut. Res., 2000, 7, 37-49

Gribble GW., 1998, Naturally occurring organohalogen compounds, Acc. Chem. Res., 31, 141-152

Gribble GW., Naturally occurring organohalogen compounds - A comprehensive survey, Prog. hem. Org. Nat. Prod., 1996a, 68, 1-498

Gribble GW., 1996b, The Diversity of Natural Organochlorines in Living Organisms,
Pure and Appl. Chem., 68(9), 1699-1812

Hale KJ., Domostoj MM., Tocher DA., Irving E., Scheinmann F., 2003, Enantiospecific formal total synthesis of the tumor and GSK-3 $\beta$ inhibiting alkaloid, (-)agelastatin A. Org. Lett. 5, 2927-2930.

Hale KJ., Domostoj MM., El-Tanani M., Campbell FC., Mason CK. 2005, Strategies and Tactics in Organic Synthesis; Harmata, M., Ed.; Academic Press: London, UK,

Hamman MT., Scheuer PJ., Kellyborges M., 1993, Biogenetically diverse, bioactive constituents of a sponge, order verongida - bromotyramines and sesquiterpene-shikimate derived metabolites, J. Org. Chem., 1993, 56, 6565 $-6569$

Hare PD., Cress PD., 1997, Metabolic implications of stress-induced proline accumulation in plants, Plant Growth Regul., 21, 79-102

Hatano K., Nogami I., Higashide E., Kishi T., 1984, Biosynthesis of enduracidin: origin of enduracididine and other amino acids, Agric. Biol. Chem., 48, 1503

He Q., Chen W., Qin Y. 2007, Synthesis of 2substituted endo-hymenialdisine derivatives. Tetrahedron Lett. 48, 18991901.

Hemscheidt T., Burgoyne DL., Moore RE., 1995, Biosynthesis of anatoxin-a(s). $(2 S, 4 S)$-4-hydroxyarginine as an intermediate, J. Chem. Soc. Chem. Commun., 205-6

Hertiani T., Edrada-Ebel R., Ortlepp S., van Soest RWM., de Voogd NJ., Wray V., Hentschel U., Kozytska S., Müller WEG., Proksch P., 2010, From Antifouling to Biofilm Inhibition of New cytotoxic secondary metabolites from two Indonesian Agelas sponges, Bioorganic and Medicinal Chemistry, 18:12971311

Hertiani T., Edrada R., van Soest RWM., Müller WEG., Sudarsono, Proksch P., 2009, Chemical investigation on Pseudoceratina purpurea collected from Banyuwangi Indonesia, Majalah Farmasi Indonesia, 20(1), 17 - 26, 2009 
Hertiani T., 2007 Isolation and Structure Elucidation of Bioactive Secondary Metabolites from Indonesian Marine Sponges, Dissertation, Heinrich-Heine Universitaet, Duesseldorf, Germany

Hoffmann H., Lindel T., 2003, Synthesis of the pyrrole-imidazole alkaloids, Synthesis, 12, $1753-1783$

Hong TW., Jímenez DR., Molinski TF., 1998, Agelastatins C and D, new pentacyclic bromopyrroles from the sponge Cymbastela sp., and potent arthropod toxicity of (-)-agelastatin J. Nat. Prod., 61, 158-161

Horii, S., Kameda Y., 1968, Structures of new basic amino acids, enduracididine and alloenduracididine, J. Antibiot., 21, 665

Hu GP., Yuan J., Sun L., She ZG., Wu J-H., Lan XJ., Zhu X., Lin YC., Chen SP., 2011, Statistical Research on Marine Natural Products Based on Data Obtained between 1985 and 2008, Mar. Drugs, 9, 514-525

Huigens R.W. III; Richards J.J.; Parise, G.; Ballard, T.E.; Zeng, W.; Deora, R.; Melander, C. 2997, Inhibition of Pseudomonas aeruginosa biofilm formation with bromoageliferin analogues. J. Am. Chem. Soc. 129, 6966-6967.

Iwagawa T., Kaneko M., Okamura H., Nakatani M., van Soest RWM., 1998, New Alkaloids from the Papua New Guinean Sponge Agelas nakamurai, J. Nat. Prod., 61 (10), pp 1310-1312

Jacquot DEN., Mayer P., Lindel T., 2004, Chiroptical analysis of marine sponge alkaloids sharing the pyrrolopyrazinone core, Chem. Eur. J., 10, 1141 - 1148

Jaffe HH., Orchin M., 1962, Theory and Application of Ultra Violet Spectroscopy, Willey, New York, 350 - 351

Kaestner, A., Invertebrate Zoology, 1967, Interscience, New York, Vol. I, 24

Kaiser, H.M.; Zenz, I.; Lo, W.F.; Spannenberg, A.; Schroeder, K.; Jiao, H.; Goerdes, D.; Beller, M.; Tse, M.K. 2007, Preparation of novel unsymmetrical bisindoles under solvent-free conditions: Synthesis, crystal structures, and mechanistic aspects. J. Org. Chem. 72, 8847-8858.
Kinnel RB., Gehrken HP., Swali R., Skoropowski G., Scheuer Paul J., 1998, Palau'amine and Its Congeners: A Family of Bioactive Bisguanidines from the Marine Sponge Stylotella aurantium, J. Org. Chem., 63, 3281-3286

Kitagawa I., Kobayashi M., Kitanaka K., Kido M., Kyogoku Y. 1983, Marine natural products. XII. On the chemical constituents of the Okinawan marine sponge Hymeniacidon aldis. Chem. Pharm. Bull. 31, 2321-2328.

Kobayashi, J., Inaba, K., and Tsuda, M., 1997, Tauroacidins $\mathrm{A}$ and B, New Bromopyrrole Alkaloids Possessing a Taurine Residue from Hymeniacidon Sponge, Tetrabedron, 53, 16679 - 16682

König G., Wright AD., 1993, Agelorins A and B, and 11-Epi-fistularin-3, Three New Antibacterial Fistularin-3 Derivatives from the Tropical Marine Sponge Agelas oroides, Heterocycles, 36, No. 6, 1351 - 1358

Lindel T., Hochgürtel M., Assmann M., Köck M., 2000a, Synthesis of the marine natural product nalpha-(4bromopyrrolyl-2-carbonyl)-L-

homoarginine, a putative biogenetic precursor of the pyrrole-imidazole alkaloids, J. Nat. Prod., 63, 1566 -1569

Lindel T., Hoffman H., Hochgürtel M., Pawlik JR., 2000b, Structure-activity relationship of inhibition of fish feeding by spongederived and synthetic pyrrole-imidazole alkaloids, Journal of Chemical Ecology, 2000b, 26 (6), 1477 -1496

Lindel T., Hoffmann H. 1997, Synthesis of dispacamide from the marine sponge Agelas dispar. Tetrahedron Lett. 38, 89358938.

Longley DB., Johnston PG. 2005, Molecular mechanisms of drug resistance. J. Pathol. 205, 275-292.

Mangu N., Kaiser HM., Kar A., Spannenberg A., Beller M., Tse MK., 2008, Synthesis of novel hymenialdisine analogues using solvent-free and silica gel-promoted ring opening of epoxides.Tetrabedron 64, 7171-7177.

Marin A., López MD., Esteban MA., Meseguer J., Muñoz J., Fontana A., 1998, Anatomical and ultrastructural studies of 
chemical defence in the sponge Dysidea fragilis, Mar. Biol., 131, 639-645

MarinLit database, 2006, Department of Chemistry, University of Canterbury Zealand:

http://www.chem.canterbury.ac.nz/mari nlit/marinlit.shtml

MarinLit database, 2002, Department of Chemistry, University of Canterbury Zealand:

http://www.chem.canterbury.ac.nz/mari nlit/marinlit.shtml

Mason CK., Mcfarlane S., Johnston PG., Crowe P., Erwin PJ., Domostoj MM., Campbell FC., Manaviazar S., Hale KJ., El-Tanani M. 2008, Agelastatin A: A novel inhibitor of osteopontinmediated adhesion, invasion, and colony formation. Mol. Cancer Ther. 7, 548-558.

Mayr H., Kempf B., Ofial AR., 2003, pNucleophilicity in carbon-carbon bondforming reactions, Acc. Chem. Res., 36, 66

Mayer AMS., Gustafson KR., 2003, Marine pharmacology in 2000: Antitumor and cytotoxic compounds, Int. J. Cancer, 105, 291-299

McClintock JB., Baker BJ. (Eds.), Marine Chemical Ecology, 2001, CRC, Boca Raton, Florida McConnel OJ., Longley RE., Koehn FE., Biotechnology, 1994, 26, 109 174

McConnel OJ., Longley RE., Koehn FE., 1994, The discovery of marine natural products with therapeutic potential, Biotechnology, 26, 109 -174

Meketa ML., Weinreb SM., 2006, Total Synthesis of Ageladine A, an Angiogenesis Inhibitor from the Marine Sponge Agelas nakamurai Org. Lett., 8 (7), pp 1443-1446

Meijer L., Thunnissen AMWH., White AW., Garnier M., Nikolic M., et al., 2000, Inhibition of cyclin-dependent kinases, GSK-3 $\beta$ and CK1 by hymenialdisine, a marine sponge constituent. Chem. Biol. 7, 51-63.

Michal, G., 1972, Biochemical Pathways, Boehringer Mannheim

Müller WEG., Diehl-Seifert B., Sobel C. Bechtold A., Kljajic Z, Dom, A., 1986, Sponge secondary metabolites: biochemical and ultrastructural localization of the antimitotic agent avarol in Dysidea avara, J. Histochem. Cytochem., 34, 1687-1690

Murti YB., 2006, Isolation and Structure Elucidation of Bioactive Secondary metabolites from sponges collected at Ujung pandang and in the Bali Sea, Indonesia, Dissertation, $61-64$

Neidleman SL., Geigert, J., 1986, Biobalogenation: Principles, Basic Roles, and Applications, Ellis Horwood Ltd., Chichester, UK, 46 - 47

Nicolaou KC., Vourloumis D., Winssinger N., Baran PS. 2000, The art and science of total synthesis at the dawn of the twentyfirst century. Angew. Chem., Int. Ed. 39, 44-122.

Olofson A., Yakushijin K., Horne DA. 1998, Synthesis of C11N5 marine alkaloids oroidin, clathrodin, and dispacamides. Preparation and transformation of 2amino-4,5-dialkoxy-4,5-

dihydroimidazoline from 2aminoimidazoles. J. Org. Chem. 63, 12481253.

Papeo G., Posteri H., Borghi D., Varasi M., 2005, A new glycocyamidine ring precursor: Syntheses of $(Z)$ hymenialdisine, (Z)-2debromohymenialdisine, and $( \pm)$-endo-2debromohymenialdisine, Org. Lett. 7, 5641-5644

Parmentier JG., Portevin B., Golsteyn RM., Pierre A., Hickman J., Gloanec P., De Nanteuil G. 2009, Synthesis and CHK1 inhibitory potency of hymenialdisine analogues. Bioorg. Med.Chem. Lett. 19, 841-844.

Pedradab S., 2005, Isolation and Structure Elucidation of Secondary Metabolites from Marine Sponges and a Marinederived Fungus, Dissertation, HeinrichHeine Universität, Düsseldorf, 71-86

Pettit GR., Ducki S., Herald DL., Doubek DL., Schmidt JM., Chapuis JC. 2005, Antineoplastic agents. 470. Absolute configuration of the marine sponge bromopyrrole agelastatin A. Oncol. Res. $15,11-20$.

Piña IC., Gautschi JT., Wang GYS., Sanders ML., Schmitz FJ., et al., 2003, 
Psammaplins from the sponge Pseudoceratina purpurea: inhibition of both histone deacetylase and DNA methyltransferase, J. Org. Chem., 2003, 68, 3866-3873

Portevin B., Golsteyn RM., Pierre A., De Nanteuil G. 2003, An expeditious multigram preparation of the marine protein kinase inhibitor debromohymenialdisine. Tetrahedron Lett. 44, 9263-9265.

Poullennec KG., Kelly AT., Romo D., 2002, Highly Diastereoselective Desymmetrizations of Cyclo(Pro,Pro): An Enantioselective Strategy toward Phakellstatin and Phakellin, Organic Letters, 4(16), 2645-2648

Proksch P., 1999, Chemical defense in marine ecosystems. In: Wink, M. (Ed.) Functions of plant secondary metabolites and their exploitation in biotechnology, Academic, Sheffield, 134- 154

Proksch P., Ebel R., 1998, Ecological significance of alkaloids from marine invertebrates. In: Roberts, M.F.; and Wink, M. (eds.), Alkealoids, biochemistry, ecology and medicinal applications, Plenum, New York, 379 - 394

Proksch P., Edrada R., Ebel R., 2002, Drugs from the seas current status and microbiological implications, App. Microbiol. Biotechnol, 59, 125-134

Quiñoà E., Crews P., 1987, Phenolic constituents of Psammaplysilla, Tetrabedron Lett., 28(28), 3229-3232

Remiszewski SW., 2003, The discovery of NVP-LAQ824: from concept to clinic, Current Medicinal Chemistry, 10(22), 23932402

Richard JP., Szymanski P., Williams KB., 1998, Solvent effects on carbocationnucleophile combination reactions, $J$. Am. Chem. Soc., 120, 10372-8

Richards JJ., Reyes S., Stowe SD., Tucker AT., Ballard TE.; Mathies LD., Cavanagh J., Melander C. 2009, Amide isosteres of oroidin: Assessment of antibiofilm activity and C. elegans toxicity. J. Med. Chem. 52, 4582-4585.

Richards, J.J.; Huigens, R.W. III; Ballard, T.E.; Basso, A.; Cavanagh, J.; Melander, C. 2008a, Inhibition and dispersion of proteobacterial biofilms. Chem. Commun. 1698-1700.

Richards JJ., Ballard TE., Melander C. 2008b, Inhibition and dispersion of Pseudomonas aeruginosa biofilms with reverse amide 2aminoimidazole oroidin analogs. Org. Biomol. Chem. 6, 1356-1363.

Richards JJ., Reed CS., Melander C. 2008c, Effects of $\mathrm{N}$-pyrrole substitution on the anti-biofilm activities of oroidin derivatives against Acinetobacter baumannii. Bioorg. Med. Chem. Lett. 18, 4325-4327.

Richards JJ., Ballard TE., Huigens RW. III; Melander C. 2008d, Synthesis and screening of an oroidin library against Pseudomonas aeruginosa biofilms. ChemBioChem., 9, 1267-1279

Richelle-Maurer E., Gomez R., Braekman JC., Van de Vyver G., Van Soest RWM., Devijver C., 2003, Localization and ecological significance of oroidin and sceptrin in the Caribbean sponge Agelas conifera, J. Biotechnol., 100, 169 - 176

Rodriguez, A.D., Piña IC., 1993, The structures of aplysinamisines I, II, and III: New bromotyrosine-derived alkaloids from the Caribbean sponge Aplysina cauliformis.J. Nat. Prod., 56(6), 907-914

Rodriquez AD., Akee, R., and Scheuer, P., 1987, Two Bromotyrosine-Cysteine Derived Metabolites from a Sponge, Tetrahedron Lett., 28, 4989-4992

Salomon CE., Deerinck T., Ellisman MH., Faulkner DJ., 2001, The cellular localization of dercitamide in the Palauan sponge Oceanapia sagittaria, Mar. Biol., 139, 313-319

Sapar A., Anwari H., Gusrizal, 2013, Identifikasi komponen lipofilik fraksi nheksan spons Agelas nakamurai asal Pulau Randayan Kalimantan Barat (Identification of lipophilic component of n-hexane fraction on Agelas nakamurai Sponge from Randayan Island, West Kalimantan), Marina Chimica Acta, 14(1): 1-11

Scala F., Fattorusso E., Menna M., TaglialatelaScafati O., Tierney M., Kaiser M., Tasdemir . 2010, Bromopyrrole Alkaloids as Lead Compounds against 
Protozoan Parasites Mar. Drugs, 8, 21622174

Schupp P., Eder C., Paul V., Proksch P., 1999, Distribution of secondary metabolites in the sponge Oceanapia sp. and its ecological implications, Mar. Biol., 135, 573-580

Sharma G., Magdoff-Fairchild B., 1977, Natural products of marine sponges. 7. The constitution of weakly basic guanidine compounds, dibromophakellin and monobromophakellin, J. Org. Chem.Vol., 42, No. 25, $4118-4124$

Shim JS., Lee HS., Shin J., Kwon HJ., 2004, Psammaplin A, a marine natural product, inhibits aminopeptidase $\mathrm{N}$ and suppresses angiogenesis in vitro, Cancer Letters, 203, 163-169

Shimizu Y., Norte M., Hori A., Genenah A., Kobayashi M., 1984, Biosynthesis of saxitoxin analogues: The unexpected pathway, J. Am. Chem. Soc., 106, 64336434

Simmons TL., Andrianasolo E., McPhail KFP., Gerwick W., 2005, Marine natural products as anticancer drugs, Mol. Cancer Ther., 4(2) 333-342

Sipkema D., Osinga R., Schatton W., Mendola D., Tramper J., Wijffels RH., 2005, Biotechnology and Bioengineering, 90 (2), 201 - 222

Smith RM., 2005,Understanding mass spectra: a basic approach, Wiley-Interscience, New Jersey

Sosa ACB., Yakushijin K., Horne DA., 2000, A practical synthesis of (Z)debromohymenialdisine., J. Org. Chem., 65, 610-611.

Stien D., Anderson GT., Chase CE., Koh YH., Weinreb SM. 1999, Total synthesis of the antitumor marine sponge alkaloid agelastatin A. J. Am. Chem. Soc. 121, 9574-9579.

Sun XT., Chen A. 2007, Total synthesis of raclongamide B. Tetrahedron Lett. 48, 3459_ 3461.

Tabudravu JN., Jaspars M., Purealidin S., Purpuramine J., 2002. Bromotyrosine alkaloids from the Fijian marine sponge Druinella sp., J. Nat. Prod., 65, 1798 1801
Tasdemir D., Topaloglu B., Perozzo R., Brun R., O'Neill R., et al. 2007, Marine natural products from the Turkish sponge Agelas oroides that inhibit the enoyl reductases from Plasmodium falciparum, Mycobacterium tubercolosis and Escherichia coli. Bioorg. Med. Chem. 15, 6834-6845.

Thompson JE., Barrow KD., Faulkner DJ., 1983, Localization of two brominated metabolites, aerothionin and homoaerothionin, in spherulous cells of the marine sponge Aplysina fistularis, Acta Zool., 64, 199-210

Travert N., Al-Mourabit A., 2004, A likely biogenetic gateway linking 2aminoimidazolinone metabolites of sponges to proline: Spontaneous oxidative conversion of the pyrroleproline-guanidine pseudo-peptide to dispacamide A, J. Am. Chem. Soc., 126, $10252-10253$

Trianto A., Ambariyanto, 2005, Isolasi Senyawa Antikanker Leukemia dari Sponge Agelas nakamurai dan Haliclona.sp, Report of "Basic Research", Fakultas Perikanan dan Ilmu Kelautan, Universitas Diponegoro.

Tsukamoto S., Kato H., Hirota H., Fusetani N. In: Watanabe, Y., Fusetani, N. (Eds.), 1998. Sponge Sciences, Springer Verlag, $399-412$

Turon X., Becerro MA., Uriz MJ., Distribution of brominated compounds within the sponge Aplysina aerophoba: Coupling of $\mathrm{X}$-ray microanalyses with cryofixation techniques, Cell Tissue Res., 2000, 301, 311-322

Uemoto H., Tsuda M., Kobayashi J., 1999, Mukanadins A-C, New Bromopyrrole Alkaloids from Marine Sponge Agelas nakamurai, J. Nat. Prod., 62 (11), pp $1581-1583$

Uriz MJ., Becerro MA., Tur JM., Turon X., 1996, Location of toxicity within the Mediterranean sponge Crambe crambe (Demospongiae: Poecilosclerida), Mar. Biol., 124, 583-590

Van Pee KH., 2001, Microbial biosynthesis of halometabolites, Arch. Microbiol., 175, 250

Wan Y., Hur W., Cho CY., Liu Y., Adrian FJ., et al., 2004, Synthesis and target 
identification of hymenialdisine analogs. Chem. Biol. 11, 247-259.

Whitehead, Roger, 1999, Natural product chemistry, Annu. Rep. Prog. Chem., Sec B, 95, $183-205$

Williams DH., Faulkner DJ., 1996. Isomers and tautomers of hymenialdisine and debromohymenialdisine, Tetrahedron, , 52(15), 5381-5390

Xu YZ., Yakushijin K., Horne DA. 1997, Synthesis of C11N5 marine sponge alkaloids: ( \pm )- Hymenin, stevensine, hymenialdisine, and debromohymenialdisine. J. Org. Chem. 62, 456-464. 